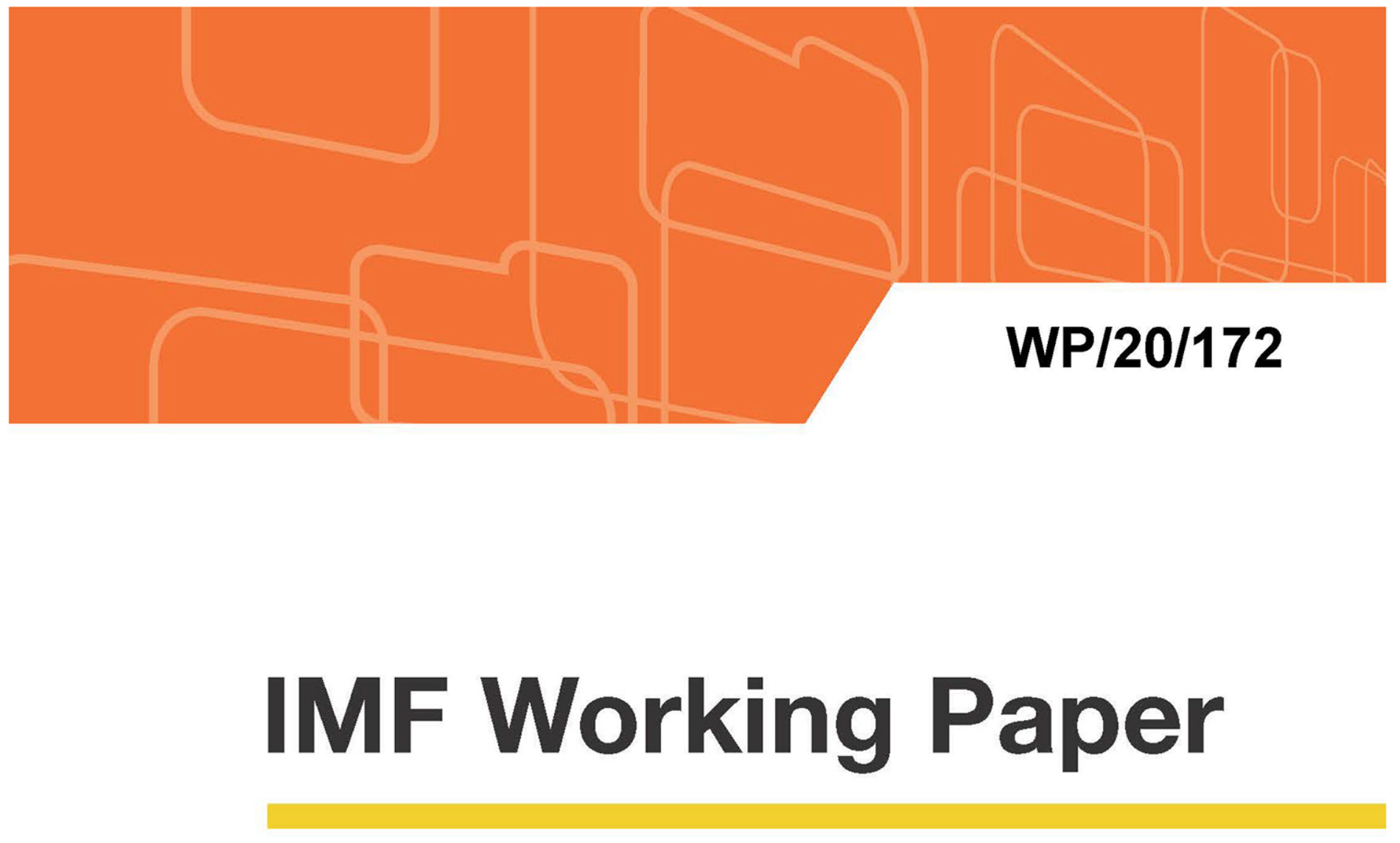

\title{
Tackling Private Over-Indebtedness in Asia: Economic and Legal Aspects
}

Jose Garrido, Sanaa Nadeem, Nagwa Riad, Chanda DeLong,

Nadia Rendak, and Anjum Rosha

IMF Working Papers describe research in progress by the author(s) and are published to elicit comments and to encourage debate. The views expressed in IMF Working Papers are those of the author(s) and do not necessarily represent the views of the IMF, its Executive Board, or IMF management. 


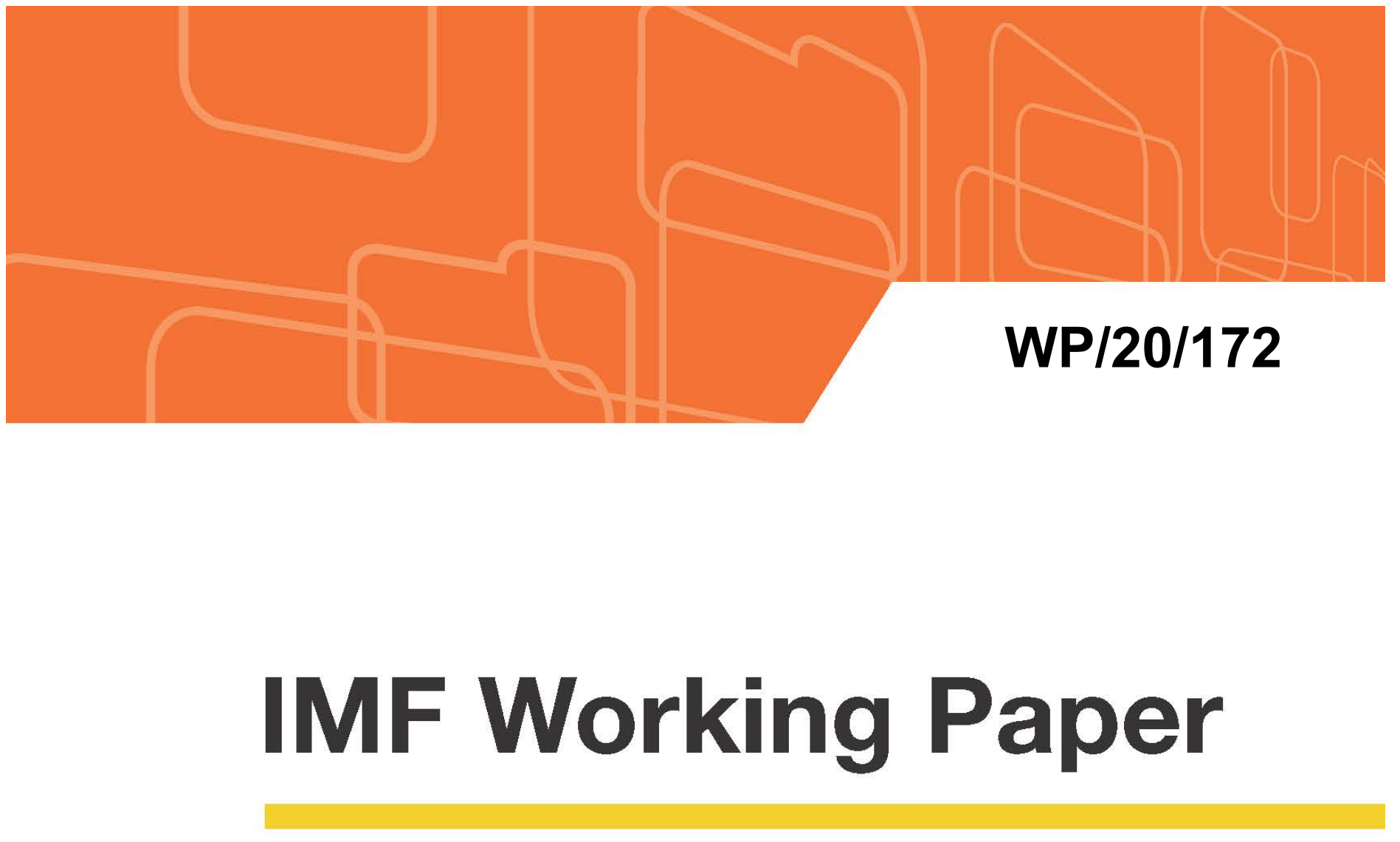

\section{Tackling Private Over-Indebtedness in Asia: Economic and Legal Aspects}

Jose Garrido, Sanaa Nadeem, Nagwa Riad, Chanda DeLong, Nadia Rendak, and Anjum Rosha

IMF Working Papers describe research in progress by the author(s) and are published to elicit comments and to encourage debate. The views expressed in IMF Working Papers are those of the author(s) and do not necessarily represent the views of the IMF, its Executive Board, or IMF management. 


\title{
IMF Working Paper
}

Asia and Pacific Department

\section{Tackling Private Over-Indebtedness in Asia: Economic and Legal Aspects \\ Prepared by Jose Garrido, Sanaa Nadeem, Nagwa Riad, Chanda DeLong, Nadia Rendak, and Anjum Rosha}

Authorized for distribution by Lamin Leigh and Yan Liu

August 2020

IMF Working Papers describe research in progress by the author(s) and are published to elicit comments and to encourage debate. The views expressed in IMF Working Papers are those of the author(s) and do not necessarily represent the views of the IMF, its Executive Board, or IMF management.

\begin{abstract}
One consequence of interest rates remaining "too low for too long" since the Global Financial Crisis is the buildup in private leverage in emerging economies. These vulnerabilities have been laid bare by the COVID-19 shock. This paper employs the growth at risk framework (Adrian, Boyarchenko, and Giannone, 2019) to examine how different types of private leverage present risks to future GDP growth in Asian economies. We find evidence that private leverage can boost GDP growth in the near term, but can increase the risks of low growth over the medium term. For our sample, we also find that household debt poses a larger drag on future GDP growth than corporate debt. In the second part of the paper, we provide an overview of a strategy for prevention and resolution of over-indebtedness, with a focus on legal tools, and with considerations to account for the consequences of the COVID-19 pandemic. Using a novel cross-country survey, we examine the role of legal techniques to prevent and treat corporate and household over-indebtedness, benchmarking those in ASEAN5, China, India, Japan and Korea against international best practice. The analysis can inform a country-specific prioritized approach to strengthening legal frameworks.
\end{abstract}

JEL Classification: D14, E44, G5

Keywords: Private debt, household debt, corporate debt, legal frameworks, insolvency

Author’s E-Mail Address: JGarrido@imf.org; SNadeem@imf.org; NRiad@imf.org 


\section{Table of Contents}

Abstract

I. Introduction,

II. Private Debt in Asia: Stylized Facts

III. The Macroeconomic Costs of Over-Indebtedness

A. What Does the Literature Tell Us?

B. Private Debt and Risks to GDP Growth

IV. Tackling Over-indebtedness: A Multipronged Approach

V. Legal Frameworks to Tackle Over-indebtedness

A. Ex-ante Tools for Enterprises

B. Ex-Ante Tools for Households

C. Ex-Post Tools for Corporates

D. Ex-Post Tools for Households

E. Legal Frameworks: Main Conclusions

F. The COVID-19 Shock and Private Debt Resolution

VI. Conclusion and Policy Recommendations

Annex I. Methodology for the Analysis of Country Legal Systems

A. Ex Ante - Enterprise

B. Ex Ante - Household

C. Ex Post - Enterprise

D. Ex post- Household

References

$\longrightarrow \frac{31}{34}$

\section{Figures}

1. Corporate and Household Debt in Advanced and Emerging Market Economies, 2007 vs. 2019

2. Private Devt vs. Growth Projections

3. The Evolution of Household and Corporate Debt (share of GDP) in Asia, 1995-2019

4. The Composition of Household Debt in China and Thailand

5. Household Debt, As a Share of GDP and Disposable Income

6. Conditional Growth Distributions Over Time

7. Shocks to Private Debt: Distribution of Real GDP Growth

8. Overview of Ex Ante and Ex Post Measures to Address Over-Indebtedness

9. Overview of Ex Ante and Ex Post Tools in Asia

10. Ex Ante Tools for Corporate Debt

11. Ex Ante Tools for Household Debt

12. Credit information systems coverage

13. Ex Post Tools for Corporate Debt

14. Ex Post Tools for Household Debt

15. Ex Ante Tools in the COVID-19 Crisis

16. Debt Resolution in the Wake of the COVID-19 Crisis

Tables

1. Macroprudential Measures to Address Household Debt

2. Ex-Ante Tools for Corporates and Households

3. Ex-Post Tools for Corporates and Households

4. Informal Debt Restructuring Mechanisms

5. Examples of Support to Debtors in Asia

6. Informal household debt restructuring in Asia

7. Agreement with Creditors

8. Personal Bankruptcy Regimes in Asia 


\section{INTRODUCTION ${ }^{1,2}$}

1. Since the global financial crisis (GFC), highly accommodative international financial conditions have fueled the rise of private debt to unprecedented levels. As of end2019, overall global debt stood at US\$257 trillion, or 320 percent of global GDP, of which private debt, i.e. corporate and household, comprise three-fourths (IIF, 2020). Asia alone accounts for nearly a third of global private debt, equivalent to approximately 250 percent of regional GDP. The surge in global private debt over the past decade has been largely driven by emerging market economies (EMEs), with several countries in Asia experiencing some of the largest increases since 2007 (Figure 1).

2. At moderate levels, private debt can support economic activity; but at high levels, it can entail macroeconomic and social costs. ${ }^{3}$ Although moderate household debt levels can help boost demand and build personal wealth, high indebtedness can curtail growth over the medium term. Over-indebted households cut back on consumption as their perception of permanent income and wealth is reduced (Mian and Sufi, 2017; IMF, 2017). High corporate debt can weigh on investment and distort resource allocation (Lamont, 1995), exerting a drag on growth. Moreover, the Great Recession not only brought to the fore the costs on growth of high levels of debt and slow balance sheet adjustment, but also potential nonlinearities in these costs (Reinhart and Rogoff 2010; Cecchetti et al. 2011; Lombardi et al. 2017). There are also social costs to over-indebtedness, especially if it leads to insolvency. Bankruptcy may stigmatize the debtor, destroying the potential of individuals to contribute to society, and discourage risk taking more generally, while being a deficient mechanism for credit recovery.

\section{The COVID-19 pandemic has laid bare the costs of pre-existing vulnerabilities} posed by high private indebtedness. In advanced and emerging economies alike, corporate and household debt burdens could become unmanageable in the face of projected sharp economic slowdown and job losses (Figure 2). Large and unprecedented fiscal support and liquidity injections by major economies have helped put a floor under the global economy during the crisis. Yet, with lingering effects of the pandemic, bankruptcies are likely to become more common as firms exhaust their cash buffers, and households forced into extreme debt distress as policy support is unwound. At the same time, actions by major central banks have boosted investor appetite, potentially driving continued buildup of financial vulnerabilities in an environment of easy financial conditions. ${ }^{4}$

\footnotetext{
${ }^{1}$ This paper has benefitted from valuable feedback from Lamin Leigh, Kenneth H. Kang, Ken Kashiwase, Manrique Saenz, Rhoda Weeks-Brown, Sean Craig, and participants at IMF seminars and at the November 2019 IMF-Bank of Thailand high-level conference Emerging Markets in the New Normal: Dealing with Rising Domestic Leverage and the International Financial Cycles. To Nhu Dao and Agnes Ignawangsih provided excellent research assistance.

${ }^{2}$ While this paper was written before the onset of the COVID-19 pandemic, its analytical thrust and policy conclusions were reinforced by it. The relevant sections of the paper have been updated to reflect for the implications of the pandemic shock.

${ }^{3}$ The terms "debt overhang" and "over-indebtedness" are used interchangeably in this paper to refer to situations of excessive debt.

${ }^{4}$ According to the June 2020 Global Financial Stability Update, aggregate assets of the Group of Ten (G10) central banks increased by US $\$ 6$ trillion between mid-January and mid-June, more than double the increase seen during the two years of the global financial crisis from December 2007.
} 


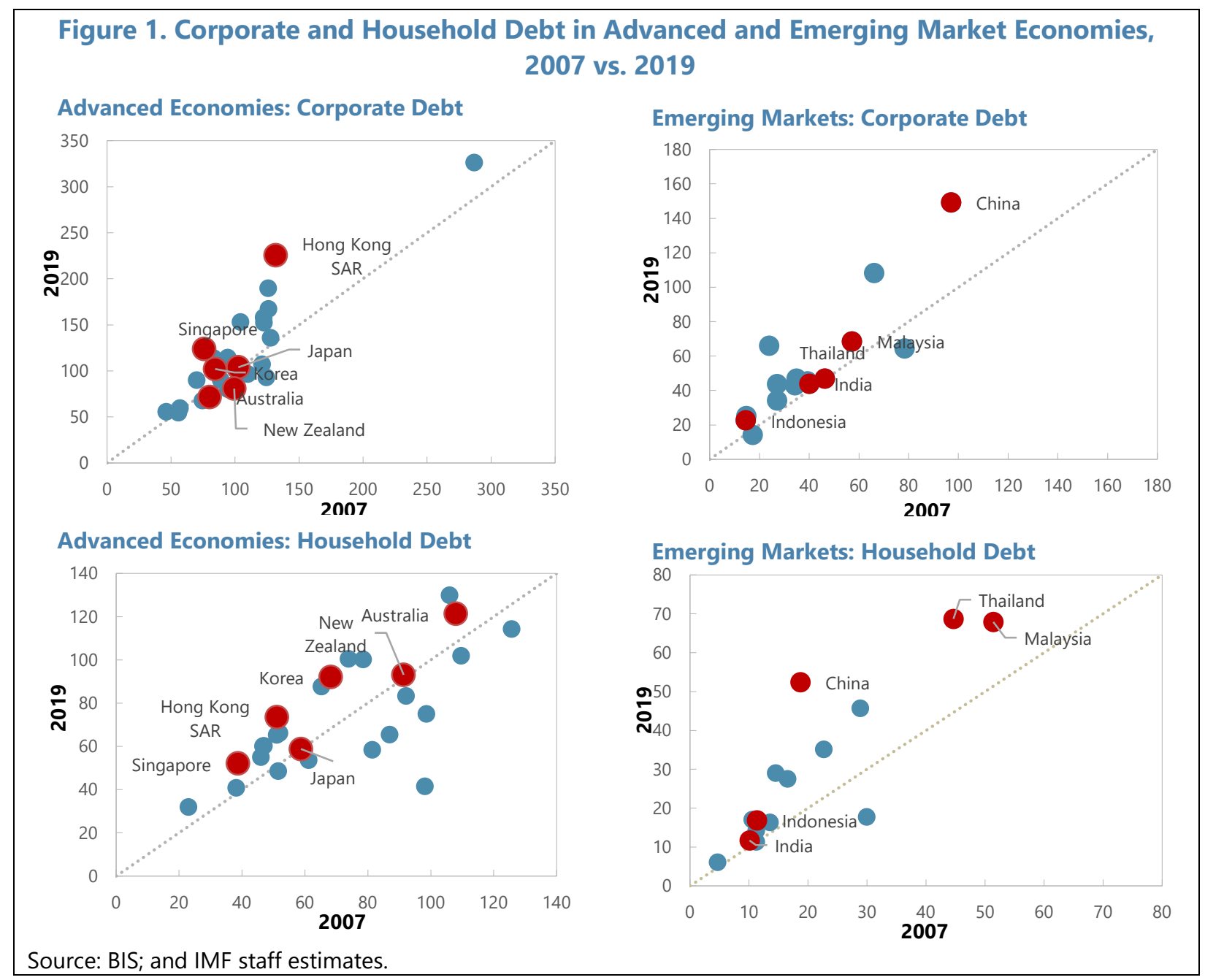

4. The current conjuncture poses challenges to Asian economies with high private debt. The impact of the pandemic on the region has been severe and unprecedented. The services sector was hit hard by the containment measures; tourism-dependent economies were impacted by the travel restrictions; and trade and manufacturing activities were disrupted. According to the June 2020 World Economic Outlook Update, emerging Asia is expected to contract by 0.8 percent in 2020, which the region has not experienced in the last 60 years. The uncertainty about the future prospects of contact-intensive sectors raises the specter of increased defaults and insolvency. Many small open Asian economies entered the crisis with

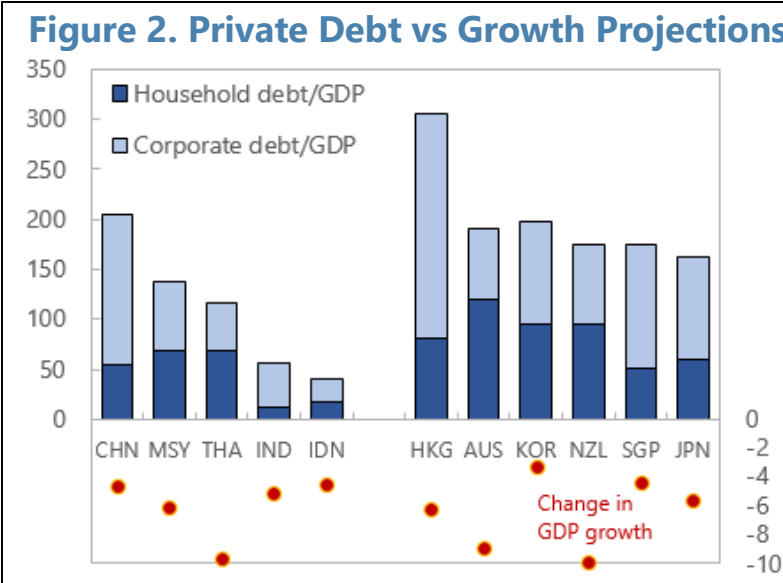

Source: June 2020 Global Financial Stability Report based on BIS, and IMF WEO database

Note: Change in GDP growth is the difference between the 2020 IMF WEO real GDP growth projections for October 2019 and April 2020. A negative number suggests a growth downgrade. 
limited downward policy space, as policy interest rates remained low since the GFC and did not rise as growth picked up. And while macroprudential policies (MPMs) are generally considered the first line of defense against excessive private debt accumulation in normal times, they may not be sufficient to counter the extensive bout of debt distress likely to be caused by the pandemic. ${ }^{5}$ Policymakers are faced with the challenge of supporting their economies while dealing with private over-indebtedness to avoid long-run economic scarring. This calls for the deployment of the all levers in their policy toolkits.

\section{Against this background, this paper argues that legal frameworks can be an} important complementary tool in policymakers' arsenal to deal with over-indebtedness, including in the context of the pandemic. In normal times, legal and other institutional structures can help reinforce macroeconomic policies and macroprudential frameworks in facilitating a proactive and orderly deleveraging. This process would typically comprise measures that tackle both the stock of debt and its flow. While international best practices in dealing with corporate debt resolution are well established, those for household debt remain emergent. In addition, standards are only emerging for preventive practices in both the corporate and household sectors. The COVID-19 shock, however, has revealed the importance of swift action by governments to strengthen national private debt resolution frameworks and adapt them to the different phases of the crisis. ${ }^{6}$

6. This paper makes three contributions. First, it applies the growth-at-risk framework (Adrian, Boyarchenko, and Giannone, 2019) to several Asian economies to examine how different types of private leverage present risks to GDP growth. Second, it provides an inventory of legal techniques to prevent and treat corporate and household over-indebtedness in several ASEAN economies, China, India, Japan, and Korea. Third, by drawing on the experience of other major Asian and advanced countries, it develops a novel approach to assess and benchmark the effectiveness of legal frameworks in these countries. These approaches then inform a set of policy priorities for ASEAN countries to help them deal with high levels of private debt at the current conjuncture, taking into account the added challenges that COVID-19 is posing for debt resolution.

7. The remainder of the paper proceeds as follows. Section II examines developments in corporate and household debt in ASEAN countries. Section III focuses on the economic costs of over-indebtedness, presenting an empirical analysis of the effects of leverage on growth using the growth-at-risk framework for four Asian countries, Korea, Japan, Singapore and Thailand. Section IV discusses the set of broad macroeconomic options available to policymakers to address over-indebtedness. Section $V$ then focuses on legal frameworks, surveying those in ASEAN-5 countries, China, India, Japan and Korea and benchmarking them against international best practice. It also lays out a sequential approach to support a tailored response to the

\footnotetext{
${ }^{5}$ Indeed, there is a view that monetary policy may be too blunt an instrument to be able to target private debt. MPMs such as loan-to-value and debt-to-income limits have been shown to be effective in controlling credit conditions (see Jácome and Mitra, 2015). More recently, IMF (2020) shows that tighter macroprudential regulation to help EMEs dampen the effect of global financial shocks. The effect, however, exhibits diminishing marginal returns, suggesting that excessive macroprudential regulation may drive financial activities outside of the regulatory perimeter.

${ }^{6}$ See Special Note on "Private Debt Resolution Measures in the Wake of the Pandemic", May 2020.
} 
challenges raised by the pandemic. Section VI concludes with policy recommendations and suggestions for future research.

\section{Private Debt in Asia: Stylized Facts}

8. Private debt had been rising rapidly in Asia after the GFC. In several Asian economies, household debt increased sharply in this period (China, Korea, and Thailand) and remains elevated (Korea and Thailand) (Figure 2). On the corporate side, despite some moderation following the Asian Financial Crisis, several countries have experienced an acceleration in corporate debt since 2008, which has grown rapidly in some cases to unprecedented levels (China, Korea, and Singapore).

9. The financial landscape has also been changing, with a growing role for nonbank institutions. Launched in 2002, the Asia Bond Market Initiative helped deepen local bond markets and reduce sovereign risk, making the region an attractive destination for capital in search of higher yields, especially after the GFC. ${ }^{7}$ On the corporate side, the rapid growth of bond markets has contributed to the shift away from bank financing. As financial systems have become larger and more complex, in many countries nonbanks (such as savings cooperatives) now account for an increasing share of household loans. Equity market growth has been slower in emerging Asia than in advanced Asian economies. The share of foreign currency denominated borrowing for both household and corporate debt has declined since the Asian Financial Crisis, which was a key source of vulnerability.

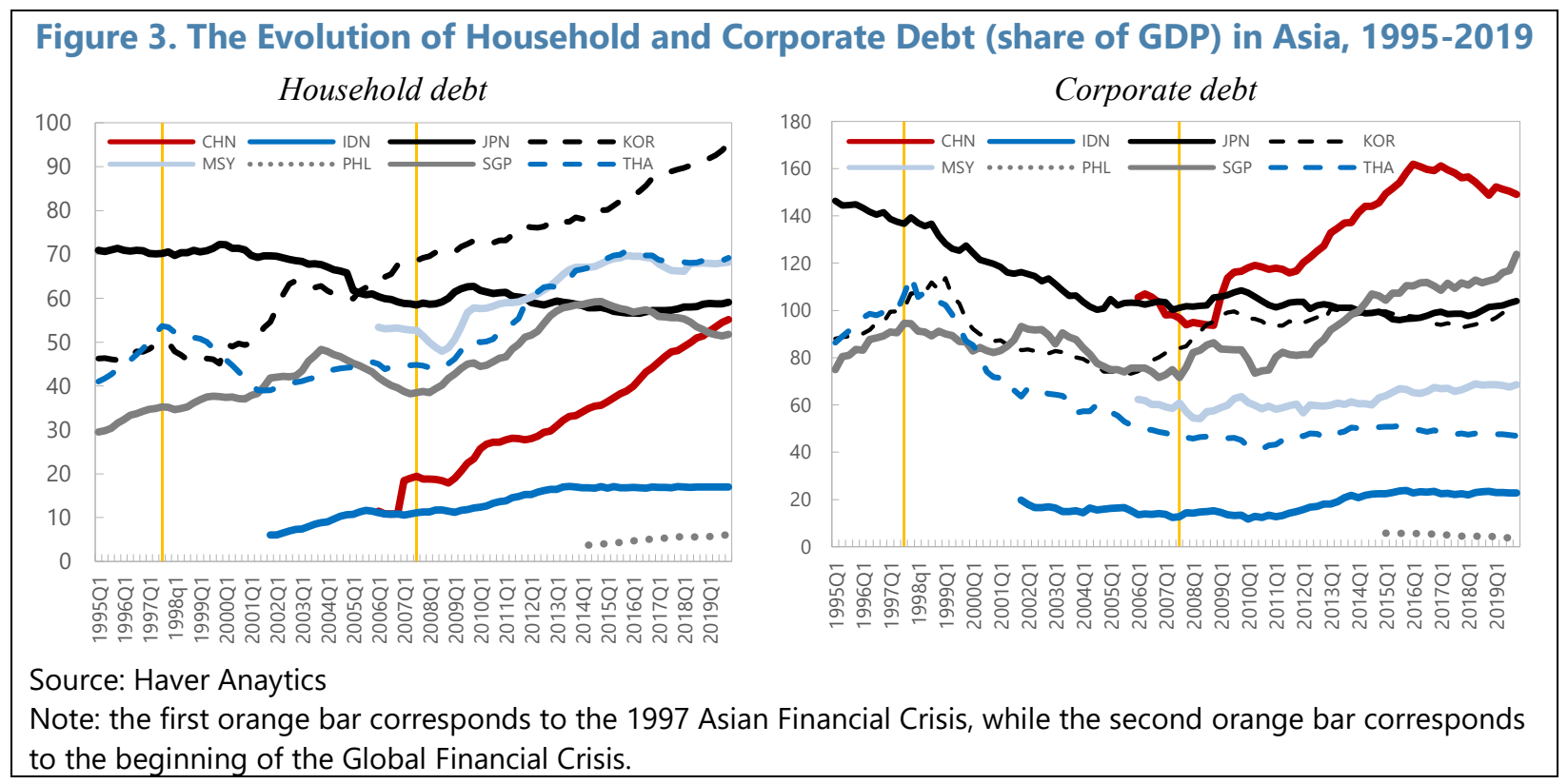

10. The drivers of corporate debt have been broadly similar across countries, with some underlying differences. As noted earlier, a common driver has been the prolonged use of

\footnotetext{
${ }^{7}$ The Asian Bond Markets Initiative (ABMI) was launched in December 2002 by ASEAN, China, Japan, and Koreacollectively known as ASEAN+3 - to develop local currency bond markets and promote regional financial cooperation (ADB, 2017).
} 
unconventional monetary policy in major AEs which pushed investors' search for yield toward more vibrant economies in the region (e.g., Korea, Thailand, and Singapore). The impact of these flows was at times amplified by country-specific factors, such as the massive stimulus in China to counter the collapse in external trade and boost domestic demand in the immediate aftermath of the GFC. The stimulus relied on rapid credit growth - a pace well in excess of optimal financial deepening - and financed a large construction boom that resulted in overstocking in the real estate and overcapacity in related upstream industries (Maliszewski et al., 2016). That said, in countries like Singapore, corporates' debt servicing capacity is supported by ample cash buffers (IMF 2019a).

\section{For household debt, the rivers in Asia have been slightly differentiated along income} levels. Housing related debt was a key driver of higher household debt in Korea, Singapore, China, and Australia. In other countries, such as Thailand, the rise in household debt was driven by consumer loans, such as auto and personal loans, which largely reflect the extension of targeted public support programs implemented in response to the 2012 floods and extended through the less regulated cooperative sector (Figure 4).

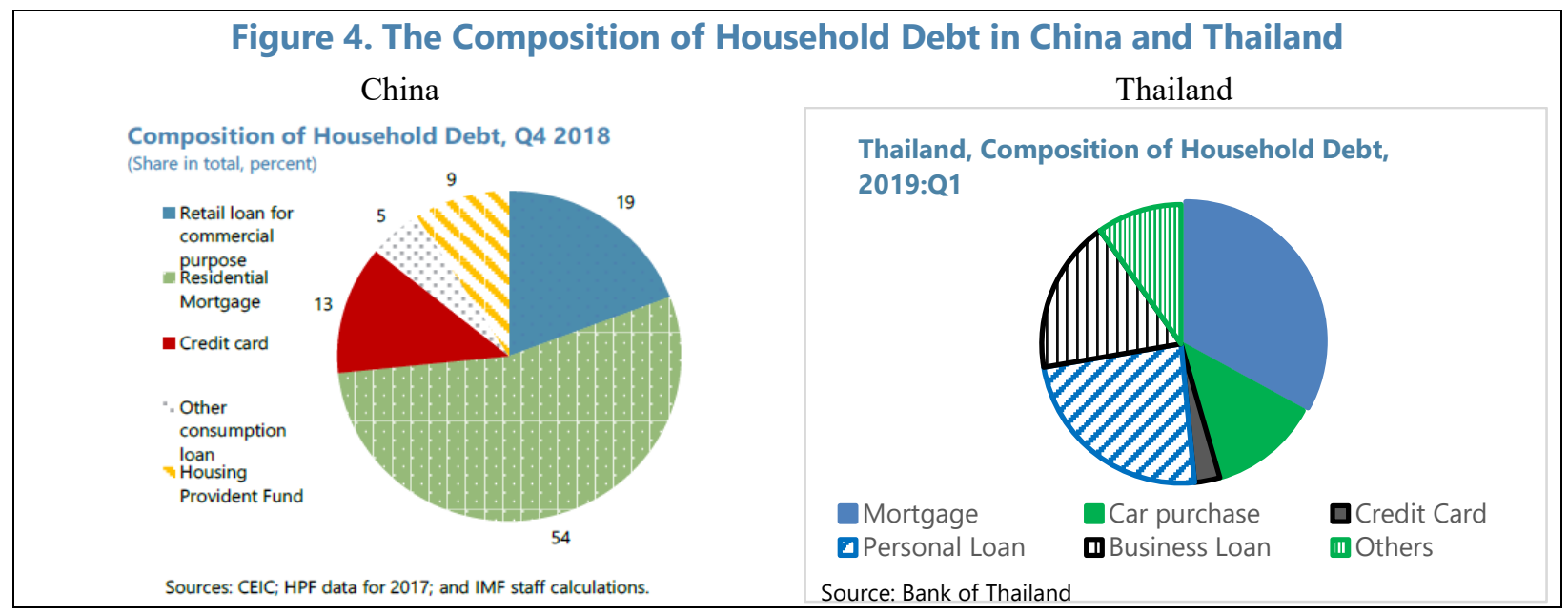

\section{In many Asian economies, the increase} in debt has outpaced disposable income

(Figure 5). Debt as share of disposable income is a closer measure of debt servicing capacity as compared to as a share of GDP. Mian and Sufi (2018) and Garber et al. (2018) identify the higher marginal propensity to consume among debtors as a crucial feature in explaining the severity of recessions following household debt expansions. More generally, the distribution of indebtedness provides a more granular assessment of the risks presented, as averages can be misleading. It is plausible that a moderate debt to GDP ratio masks a small share of very

Figure 5. Household debt, as a share of GDP and disposable income

highly indebted segments, which can pose large costs to the economy if they are distressed (see Loukoianova et al. 2019). 


\section{The Macroeconomic Costs OF OVER-IndebTedness}

\section{A. What Does the Literature Tell Us?}

13. Leverage is an essential pillar of the economy, but at high levels, it can be a source of macroeconomic vulnerabilities. In the context of financial deepening, leverage provides avenues to support financial intermediation, consumption, investment and growth. ${ }^{8}$ Yet, the Asian Financial Crisis and the Great Recession illustrate the macroeconomic costs of high debt and slow balance sheet adjustment. High corporate debt can weigh on investment and distort resource allocation; excessively leveraged firms have persistently lower investment, which in turn dampen productivity growth (Gebauer et al., 2017). Recent research on Asia finds that excessively leveraged "zombie" firms had persistently lower tangible and intangible investment, which in turn dampened productivity growth (IMF, 2018). Similarly, over-indebted households are likely to cut back on consumption as their perception of permanent income and wealth is reduced (King, 1994). Mian and Sufi (2018) and Garber et al. (2018) identify higher marginal propensity to consume among debtors as a crucial feature in explaining the severity of recessions following household debt expansions. Vulnerabilities from household debt can build up faster if it outpaces disposable income, a closer measure of debt servicing capacity.

\section{The effect of leverage on growth is likely nonlinear, with large costs to growth} beyond some threshold and over the medium term. Building on pioneering work by Reinhart and Rogoff (2010) on "tipping points," Cecchetti et al. (2011) estimate this threshold at 85 percent of GDP for households and 90 percent for corporates. IMF (2017) finds that an increase in household debt has a positive contemporaneous relationship to GDP growth and consumption and a negative association in the future (three years ahead). An increase in the household debt-to-GDP ratio raises long-term growth as long as the final ratio is below a threshold between 36 percent and 70 percent of GDP. Similar intertemporal results (see Lombardi et al., 2017), find the negative long-run effects on consumption intensify as the household debt-to-GDP ratio exceeds 60 percent, and 80 percent for GDP growth. This strand of analysis, however, assumes that tipping points are time invariant; more recent work has explored time- and state-dependent thresholds (Yang and $\mathrm{Su}, 2018$ ).

15. To move beyond threshold-based methods and to better capture nonlinearities, this paper uses the Growth at Risk methodology. By linking current macrofinancial conditions to the quantiles of future output growth, such methods move beyond focusing on a point estimate of the impact of debt on growth. It seeks to exploit partial correlations between a large set of macrofinancial variables to deliver insights on the entire growth distribution and the relative importance of its key drivers.

\footnotetext{
${ }^{8}$ Using a panel of 30 countries over the past 40 years, Mian and Sufi (2017) show that a rise in the household debt to GDP ratio increases consumption in the near term but systematically predicts lower subsequent growth and a rise in unemployment. IMF 2017 finds that an increase in household debt has a positive contemporaneous relationship to GDP growth and consumption and a negative association in the future (three years ahead).
} 


\section{B. Private Debt and Risks to GDP Growth}

\section{To assess the risk to output growth from private leverage, the conditional} distribution of GDP growth in Asian countries is estimated. This involves estimating quartile regressions of GDP growth on various macrofinancial variables that are grouped into partitions: each partition comprises up to the first three principal components to reduce dimensionality. The quartile regression estimates are then used to parametrically fit a t-skew conditional distribution of GDP growth. ${ }^{9}$

\section{For this analysis, we run quantile regressions of a country's GDP growth $y_{t} q$} quarters ahead on the following regressor groups: output growth in period $t$, financial conditions, trade partner macroeconomic conditions, and measures of private leverage (household and corporate):

$$
y_{t+q}=\beta_{y}^{q} y_{t}+\beta_{f}^{q} f i n_{t}+\beta_{t p}^{q} t_{t}+\beta_{l}^{q} \operatorname{lvg}_{t}+\varepsilon_{t+q}^{q}
$$

Financial conditions consist of credit growth, sovereign and corporate bond spreads, REER change and volatility, terms of trade, VIX, and equity and house price growth. Trade partner macroeconomic indicators comprise US and China GDP growth. Private leverage comprises household and corporate debt to GDP ratios (level and change). ${ }^{10}$ The model uses quarterly data from 1995:Q1 to 2018:Q4, with one period lags to address for potential endogeneity. ${ }^{11}$ From the estimated quantile coefficients, we fit the individual conditional GDP growth distribution for four Asian economies: Japan, Korea, Singapore, and Thailand. ${ }^{12}$

18. The estimated conditional distributions of GDP growth in the baseline suggest risks are tilted to the downside over the medium term. Figure 6 plots the mode (central tendency)

\footnotetext{
${ }^{9}$ Following the methodology in Adrian et al. 2019, the estimated quartile regression coefficients are used to estimate the parameters of t-skew distribution: $f(y ; \mu, \theta, v)=\frac{2}{\sigma} t\left(\frac{y-\mu}{\sigma}, v\right) T\left(\theta \frac{y-\mu}{\sigma} \sqrt{\frac{v+1}{v+\frac{y-\mu}{\sigma}}} ; v+1\right)$ where $\mathrm{t}(\cdot)$ and $\mathrm{T}(\cdot)$ are the PDF and CDF of the Student $t$-distribution; $\mu$ is the location, $\sigma$ is the scale, $\theta$ is the shape and $v$ is the fatness. For each, we choose the four parameters $\left\{\mu_{\mathrm{t}}, \sigma_{\mathrm{t}}, \alpha \mathrm{t}, v_{\mathrm{t}}\right\}$ of the skewed t-distribution $\mathrm{f}$ to minimize the squared distance between our estimated quantile function $\mathrm{Qy}_{\mathrm{t}}+\mathrm{h} \mid \mathrm{x}_{\mathrm{t}}(\tau)$ from (2) and the quantile function of the skewed t-distribution $\mathrm{F}-1\left(\tau ; \mu_{\mathrm{t}}, \sigma_{\mathrm{t}}, \alpha_{\mathrm{t}}, v_{\mathrm{t}}\right)$ from (3) to match the $10,25,75$, and 90 percent quantiles:

${ }^{10}$ We use this specification for two reasons. First, debt/GDP is a slow moving variable, and a change in debt may better capture short-term vulnerabilities. Second, we include household and corporate debt together in the same specification to be able to comment on the increase in one type of debt controlling for the other. However, household and corporate debt could likely be correlated. To address this, we include both the level and change for each type of debt's principal components, as this would better capture independent dynamics. As an additional robustness check, we also use include household and corporate debt variables separately in individual specifications, with similar results. Data on debt to disposable income is limited.

${ }^{11}$ Given the data intensive nature of the exercise, we are limited by the choice of sufficient instruments that could better capture endogeneity.

${ }^{12}$ Individual economies are selected based on data availability.
} 
and left tail of the baseline conditional distribution of GDP growth for each of the four countries in our sample over time. The left tail of the growth distribution is measured by the GAR $5 \%$, the level of growth below which 5 percent of the growth distribution lies. We note that in most cases, the mode and GAR5\% decline over the medium term. This showcases the potential risks to future growth from current macrofinancial conditions, which include the "low for long" accommodative global financial conditions and elevated leverage for the countries in the sample. Figure 6 plots the conditional growth distributions (black lines) over time. We notice that these baseline conditional GDP distributions are asymmetric, i.e., with a fat left tail, highlighting the nonlinear impact of macrofinancial conditions, including leverage, on growth. The estimated coefficients for household and corporate debt differ over the distribution, with often larger coefficients at the left tail of the growth distribution rather than the mean and upper tail.

\section{We next compare the impact of an increase in different types of leverage on the} GDP growth distribution, over the near and medium term. ${ }^{13} \mathrm{We}$ consider an increase in household and corporate leverage separately, controlling for the other. Figure 7 shows the impact to the growth distribution of an increase in household (blue) and corporate (red) leverage, in the short run (first row), and the medium term (second row). We note:

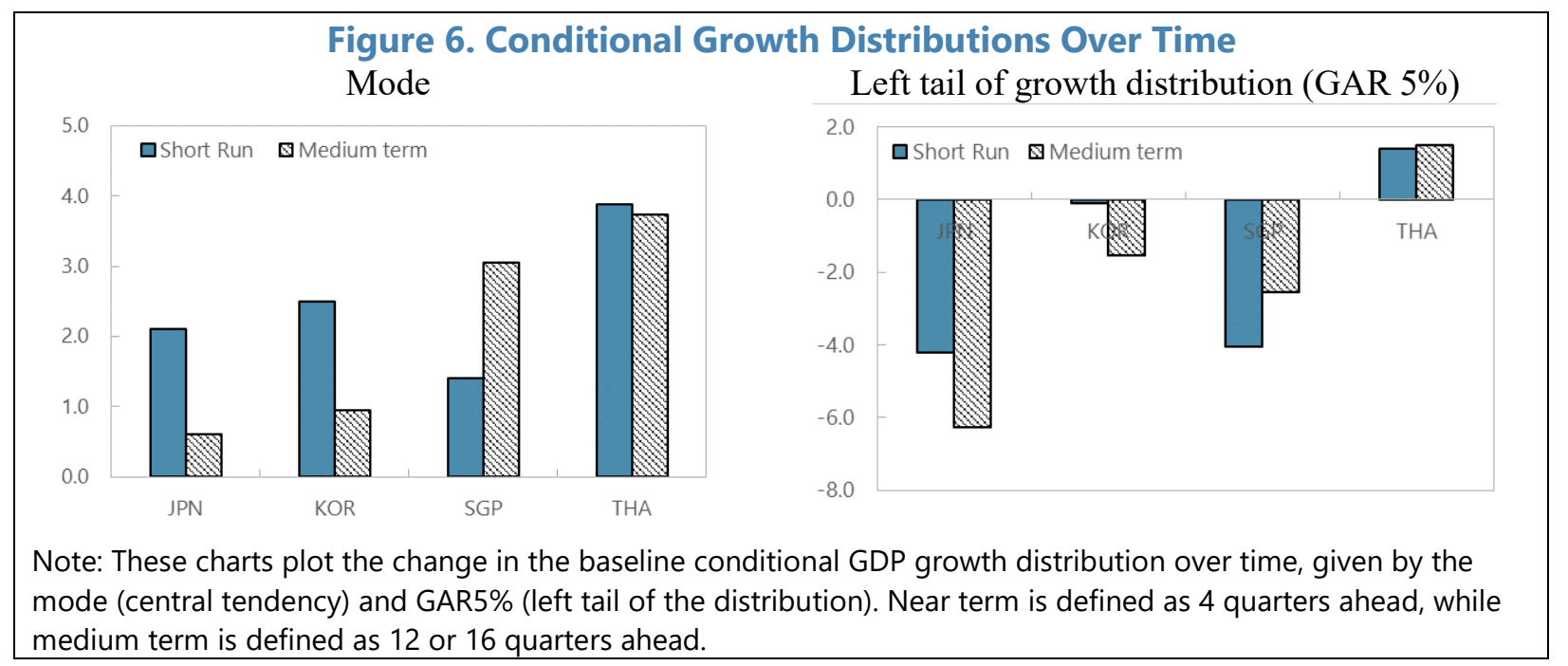

- First, on the time dimension, in some cases both household and corporate debt appear to support growth in the short run. An increase in household and corporate leverage does not result in a large leftward shift of the growth distribution; in many cases, the mode of the distribution indeed shifts to the right. However, this boost to growth from household debt is more short-lived than that from corporate debt. This is consistent with findings in the literature that in the very short run, higher household debt may boost growth (see Mian et al., 2015; IMF, 2017).

- Second, in most countries, the drag of household debt on growth tends to last throughout the growth distribution, while corporate debt tends to be concentrated only at the lower end of

\footnotetext{
${ }^{13}$ An increase is defined as a one standard deviation increase in the household or corporate debt partition.
} 
the distribution. ${ }^{14}$ A one standard deviation shock to the corporate debt/GDP ratio shifts the distribution of GDP growth to the left but by less over the medium term, with a smaller decline in the mode and the left tail thickens but by a smaller degree.

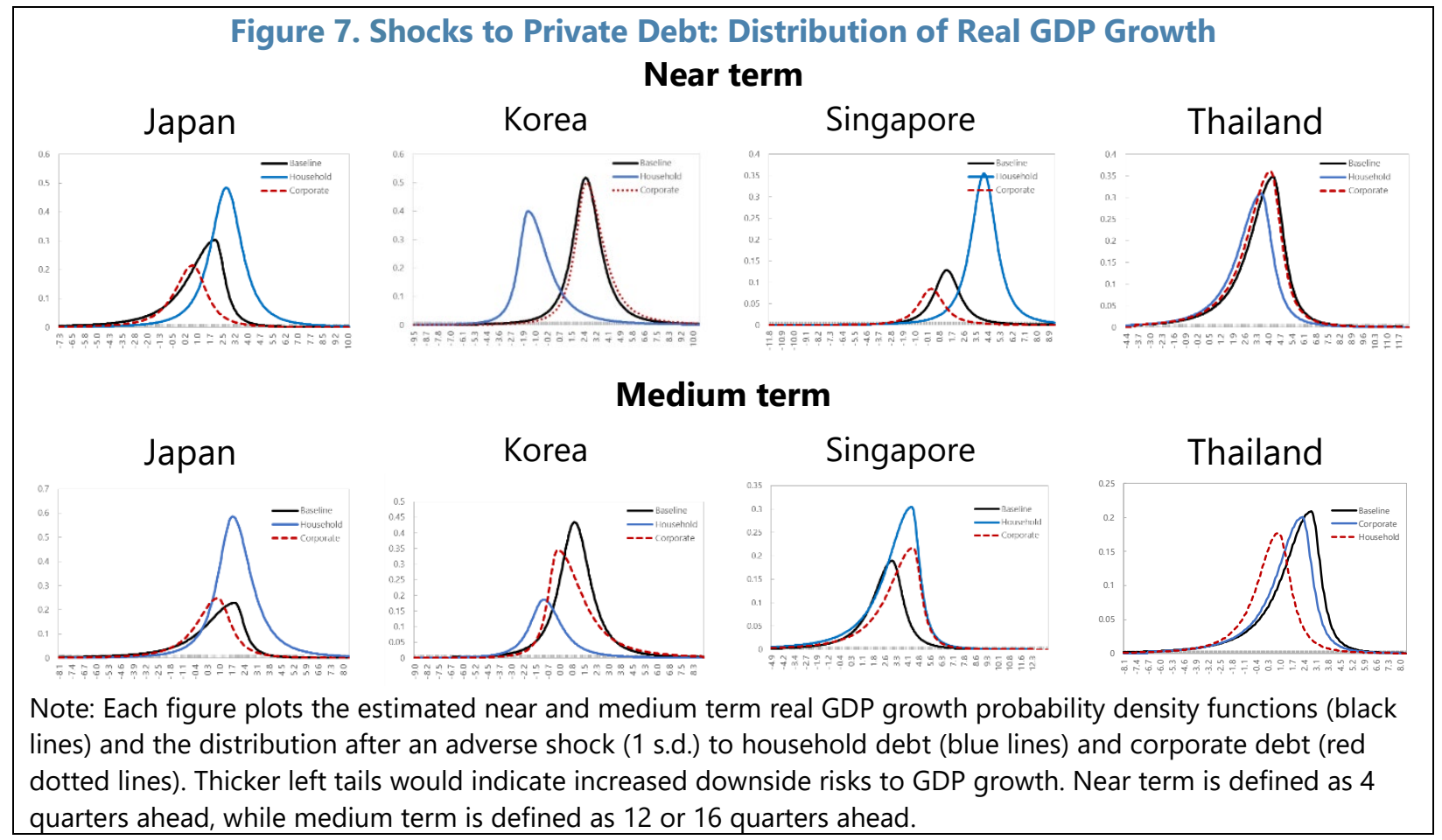

\section{This differential impact could be explained by the preexisting levels and} composition of debt, as well as the importance of private consumption as a growth driver. For many of these countries, household debt levels are higher than corporate debt levels. ${ }^{15}$ Household debt in these countries has also leaned towards fueling consumption (via personal consumer loans) rather than productive investment, which has in turn been a significant driver of growth in many Asian economies in recent years. On the institutional side, legal and institutional frameworks could also play an important role: for many of these advanced economy cases with highly developed corporate debt markets and insolvency frameworks, the avenues to service and grow out of corporate leverage are multifold. By comparison, options for managing household debt (particularly at lower income levels) may be more limited, raising the costs to growth in the face of adverse outcomes that the pandemic has made all too likely.

\section{TACKLing OVER-Indebtedness: A Multipronged APPROACH}

\footnotetext{
${ }^{14}$ The outsize role of corporate debt at the tail reflect that the bottom percentile contains observations covering the Asian Financial Crisis.

${ }^{15}$ For these countries, household debt levels are also close to or above high-risk thresholds identified by the literature (see Lombardi, Mohanty, and Shim 2017).
} 
21. The above analysis underscores the importance of building resilience against high leverage. High private leverage can pose risks to growth in the medium term. It is important to have appropriate policies both to prevent over-indebtedness from arising in the first place, as well as procedures to manage the stock of debt. Both approaches are needed for orderly deleveraging in normal times. However, with an expected increase in debt burdens and defaults due the pandemic, a sequential approach focusing on "upscaling" certain tools can be helpful in flattening the curve of insolvencies, as detailed in the next section.

22. A multipronged approach, comprising macroeconomic policies, micro- and macroprudential and fiscal tools, and legal measures can help prevent and address overindebtedness in normal times. ${ }^{16} \mathrm{~A}$ robust and mutually reinforcing policy framework can enable countries to operate with higher levels of debt and be more responsive to shocks when they occur.

- Macroeconomic policies that support growth can help households and corporates grow out of indebtedness, by bolstering their capacity to repay.

- Institutional frameworks that build financial resilience can enable countries to safely carry higher household debt. In general, countries with stronger supervisory frameworks were able to safely operate with high debt, and therefore attenuate the urgency for sub-optimal and costly deleveraging (IMF, 2017a).

- Macroprudential policies can also help countries address pockets of risk. Macroprudential frameworks to deal with corporate leverage are relatively underdeveloped, although the use of debt-at-risk analysis is becoming more sophisticated (e.g. Singapore), and existing measures have tended to focus on household debt. Several countries in Asia have indeed both deployed and strengthened macroprudential measures to deal with high household debt (Table 1).

- Fiscal policy that removes tax distortions toward leverage can also contribute to financial stability. Excessive private leverage can be amplified by tax provisions that favor finance by debt rather than equity - known as the debt bias. For corporates, the bias is induced through the deductibility of interest but not equity costs for the corporate income tax; for households, it is induced from the mortgage interest deductions (IMF, 2016). Addressing debt bias should feature prominently in countries' tax reform plans aimed at deleveraging. These could include gradual reform of tax deductions for mortgage interest and limiting interest deductibility for corporates combined with an 'allowance for corporate equity" system (to mitigate a possible loss of revenue). Fiscal policies can also be reactive by providing support to over-indebted households. It is important, however, that fiscal measures do not distort competition (i.e. do not provide subsidies for failing enterprises).

\footnotetext{
16 The macroeconomic response to the COVID-19 shock in terms of fiscal, monetary, and financial policy support is extensively covered in the April 2020 World Economic Outlook, Global Financial Stability Report and Fiscal Monitor, as well as the June 2020 World Economic Outlook Update, and is therefore not taken up in this section.
} 


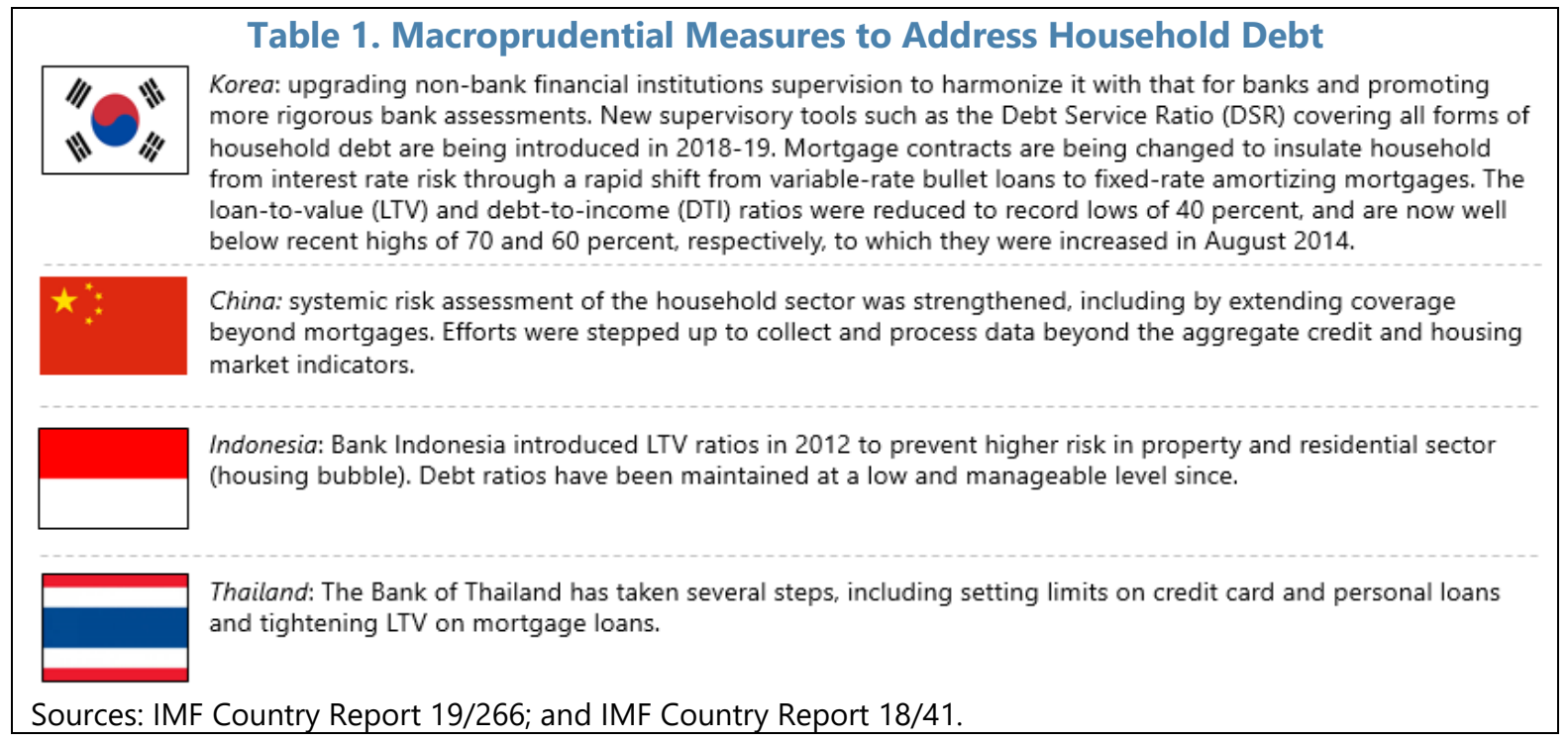

- With constraints to macroeconomic policy space, legal tools can become a potent weapon in the arsenal. For many small open economies with high or rising leverage, low global interest rates and headwinds to growth make it challenging to raise growth without further fueling financial stability risks. Legal tools can also be an important complement for dealing with the consequences of credit growth outside the regulatory perimeter of the financial system. In this setting, this paper explores the role of legal tools in addressing overindebtedness to deleverage in an orderly manner.

\section{LEGAL FrAMEWORKS TO TACKLE OVER-INDEBTEDNESS}

23. Legal frameworks are critical to dealing with over-indebtedness. In normal times, the legal system provides mechanisms for enforcing contractual rights, including credit, and can also regulate situations where multiple creditors compete to enforce over the insufficient assets of the debtor (insolvency). The legal system promotes payment discipline and discourages strategic behavior by debtors. At the same time, the law must offer efficient solutions to preserve the value of viable enterprises and provide a second chance to honest but unfortunate debtors.

\section{An effective strategy involves both ex-ante and ex-post debt measures. Over-} indebtedness of enterprises and households has negative consequences for debtors, creditors, and for the economy as a whole. ${ }^{17}$ Legal frameworks therefore should include preventive measures to contain high levels of debt before they become unsustainable (ex-ante measures), and reactive measures that address the problem of over-indebtedness once it materializes (ex-post measures) to support orderly deleveraging. For the purposes of this paper, the dividing line between ex ante and ex post strategies is set in the intervention of the judiciary. Judicial insolvency proceedings can entail large direct and indirect costs. We thus define preventive or ex ante techniques as

\footnotetext{
${ }^{17}$ We use the terms "enterprises" as equivalent to "corporates" and the term "household" to refer to individuals or consumers. In the legal literature, the basic distinction is between enterprise or business insolvency and consumer insolvency; or between corporate insolvency and individual insolvency.
} 
those that typically avoid these costly formal judicial proceedings. ${ }^{18} \mathrm{~A}$ simplified overview of the measures for addressing household and enterprise debt is illustrated in Figure 8. Tables 2 and 3 provide a brief description of each measure under ex-ante and ex-post approaches respectively.

\begin{tabular}{|c|c|c|c|c|c|c|}
\hline \multicolumn{7}{|c|}{ Figure 8. Overview of Ex Ante and Ex Post Measures to Address Over-Indebtedness } \\
\hline \multirow[b]{2}{*}{ Household } & \multirow[b]{2}{*}{$\begin{array}{l}\text { Credit } \\
\text { information } \\
\text { systems }\end{array}$} & \multirow[b]{2}{*}{$\begin{array}{l}\text { Advice to } \\
\text { debtors }\end{array}$} & \multicolumn{2}{|c|}{$\begin{array}{l}\text { Formal judicial } \\
\text { resolution process }\end{array}$} & \multirow[b]{2}{*}{$\begin{array}{l}\text { Bankruptcy: } \\
\text { repayment } \\
\text { plans }\end{array}$} & \multirow[b]{2}{*}{$\begin{array}{l}\text { Debt } \\
\text { enforcement }\end{array}$} \\
\hline & & & $\begin{array}{l}\text { Informal debt } \\
\text { restructurings }\end{array}$ & $\begin{array}{l}\text { Bankruptcy: } \\
\text { Liquidation }\end{array}$ & & \\
\hline & \multicolumn{3}{|c|}{ EX ANTE } & \multicolumn{3}{|c|}{ EX POST } \\
\hline Enterprise & $\begin{array}{l}\text { Financial and } \\
\text { economic } \\
\text { information }\end{array}$ & $\begin{array}{l}\text { Early warning } \\
\text { systems }\end{array}$ & $\begin{array}{l}\text { Informal debt } \\
\text { restructurings }\end{array}$ & Reorganization & Liquidation & $\begin{array}{c}\text { Debt } \\
\text { enforcement }\end{array}$ \\
\hline
\end{tabular}

25. The emerging trend is to focus on the prevention of over-indebtedness. Traditionally, legal measures focused on the treatment of over-indebtedness ex-post through enterprise and consumer insolvency. Whereas an international standard for enterprise insolvency exists (UNCITRAL Legislative Guide and World Bank Principles), there is no internationally accepted standard for consumer insolvency, due to wider differences in social and political approaches to consumer debt. There is a growing trend in many countries to adopt ex-ante tools that would prevent insolvency from arising in the first place. These measures are recent, both for enterprises and consumers, and therefore there are no international standards for them, only emerging best practices.

26. An inventory and evaluation of the legal frameworks for dealing with corporate and household debt is provided for a number of Asian countries. Figure 9 summarizes the findings of a review of legal systems in the ASEAN-5 countries plus four of the largest Asian economies (China, Japan, India, and Korea), using a novel approach for scoring each tool. The underlying methodology for ranking ex-ante and ex-post tools is explained in Annex I. ${ }^{19}$

\footnotetext{
${ }^{18}$ Some of the measures considered as preemptive in this paper (informal debt restructuring) could an also be utilized once over-indebtedness manifests itself but those measures may not be as effective to address it.

19 The analysis includes the ASEAN-5 countries (Indonesia, Malaysia, The Philippines, Singapore, and Thailand), and the four largest Asian economies (China, India, Japan and Korea).
} 


\begin{tabular}{|c|c|}
\hline \multicolumn{2}{|r|}{$\frac{\text { Table 2. Ex-Ante Tools for Corporates and Households }}{\text { Corporates }}$} \\
\hline $\begin{array}{l}\text { Credit and financial } \\
\text { information }\end{array}$ & $\begin{array}{l}\text { Adequate financial information on enterprises is a prerequisite for preventive } \\
\text { approaches and is only possible with a developed legal infrastructure in place. It } \\
\text { plays an enabling role not only for other preventive legal measures, but also for the } \\
\text { appropriate monitoring of enterprise debts by financial entities and supervisors, } \\
\text { including the implementation of macroprudential tools. There are two main sources } \\
\text { of credit and financial information for enterprises: credit registries (public) and credit } \\
\text { bureaus (private). These sources provide information about defaults, levels of debt, } \\
\text { and general creditworthiness. Financial statements provide the most complete } \\
\text { information on the financial and economic situation of enterprises, especially when } \\
\text { the information is prepared according to widely accepted accounting standards and } \\
\text { is subject to auditing. Information in financial statements allows creditors and } \\
\text { supervisors to analyze indicators of enterprise distress and risk of insolvency, such } \\
\text { as the Z-score (Altman, 1968). }\end{array}$ \\
\hline Early warning systems & $\begin{array}{l}\text { Early warning systems for enterprise indebtedness draw on existing systems for } \\
\text { supervised financial institutions and require the collection of abundant data from } \\
\text { enterprises, especially on different sources of debt (bank debt, taxes, social security } \\
\text { contributions). This allows for the identification of risks and the implementation of } \\
\text { strategies that address problems before the company becomes seriously distressed. } \\
\text { The main advantage of early identification of distress is that the number of available } \\
\text { restructuring options is higher, and financial institutions may be able to react before } \\
\text { their loans are classified as non-performing. }\end{array}$ \\
\hline $\begin{array}{l}\text { Informal debt } \\
\text { restructuring } \\
\text { mechanisms }\end{array}$ & $\begin{array}{l}\text { Informal debt restructuring mechanisms represent a tested approach to avoid over- } \\
\text { indebtedness and insolvency, and typically involve the debtor and its major financial } \\
\text { creditors. In some cases, banking associations and central banks have promoted } \\
\text { "debt restructuring principles" that include guidelines for the behavior of debtors } \\
\text { and creditors during restructuring negotiations. Informal debt restructuring avoids } \\
\text { the costs of formal insolvency processes and allows for a flexible resolution of } \\
\text { distress in a confidential environment. }\end{array}$ \\
\hline \multicolumn{2}{|r|}{ Households } \\
\hline $\begin{array}{l}\text { Credit information } \\
\text { systems }\end{array}$ & $\begin{array}{l}\text { Credit information systems are instrumental for the containment of household debt } \\
\text { and can collect negative and positive information about credit relationships and } \\
\text { payment patterns in other transactions, such as utilities and telecommunications. }\end{array}$ \\
\hline Advice to debtors & $\begin{array}{l}\text { Specialized legal and financial advice is often needed when households are } \\
\text { confronted with debt problems. One of the most important issues for debtors' } \\
\text { counseling is advice on the different options consumers have for restructuring their } \\
\text { debts. }\end{array}$ \\
\hline $\begin{array}{l}\text { Informal debt } \\
\text { restructuring } \\
\text { (including agreements } \\
\text { to avoid insolvency) }\end{array}$ & $\begin{array}{l}\text { Informal debt restructuring is typically the last option to avoid the use of bankruptcy } \\
\text { procedures. As households experience debt distress, the legal system can offer } \\
\text { alternative dispute resolution (ADR) solutions. Beyond simple contractual } \\
\text { negotiation, these techniques include mediation, conciliation, and arbitration. ADR } \\
\text { avoids the involvement of the courts and the costs and legal consequences of a } \\
\text { formal insolvency procedure. Informal debt restructuring can also be supported by } \\
\text { the public administration. This can be done, for instance, by establishing a } \\
\text { mediating role for financial supervisors or specialized financial consumer protection } \\
\text { authorities. Financial institutions may commit to seek negotiated solutions with } \\
\text { consumers following the provisions of a code of conduct issued by the bank } \\
\text { supervisor or by the financial industry itself. This is part of the reasonable } \\
\text { forbearance that financial institutions exercise in respect of distressed borrowers. }\end{array}$ \\
\hline
\end{tabular}




\begin{tabular}{|c|c|}
\hline \multicolumn{2}{|r|}{ Corporates } \\
\hline Reorganization & $\begin{array}{l}\text { Reorganization procedures are the hallmark of modern insolvency regimes. They } \\
\text { prevent the destruction of economic value by allowing viable companies to be } \\
\text { restructured, resulting in higher recovery values for creditors, the preservation of } \\
\text { businesses, jobs and contractual relationships. }\end{array}$ \\
\hline Liquidation & $\begin{array}{l}\text { Liquidation proceedings represent the safety valve of the insolvency system and are } \\
\text { the main instrument to deal with non-viable enterprises. The goal to make the } \\
\text { enterprise exit the market, redeploying assets to more productive uses and } \\
\text { minimizing to the extent possible the losses of creditors. The regulation of } \\
\text { liquidation proceedings follows a similar scheme in most jurisdictions, in Asia and } \\
\text { globally. } \\
\text { The effectiveness of the liquidation process depends on several legal and economic } \\
\text { factors, including (i) whether the sale of assets is conducted swiftly and without } \\
\text { incurring high costs; and, (ii) whether the system allows the possibility of selling the } \\
\text { business as a going concern, which increases the overall recovery of claims } \\
\text { (although this may need to impose some restrictions on secured creditors). } \\
\text { However, sales of enterprises or enterprise units require a developed market. } \\
\text { Naturally, the quality of institutions (courts and insolvency administrators) directly } \\
\text { affects the quality of the liquidation process. }\end{array}$ \\
\hline Debt enforcement & $\begin{array}{l}\text { Debt enforcement provides the foundation for the insolvency system. Over- } \\
\text { indebtedness of enterprises typically involve multiple creditors, which requires } \\
\text { complex, multilateral insolvency proceedings. Basic enforcement mechanisms } \\
\text { provide a response to default in credit relationships, minimizing moral hazard and } \\
\text { promoting debt discipline and credit recovery. In addition, strong debt enforcement } \\
\text { mechanisms provide the backdrop for meaningful debt restructuring negotiations. }\end{array}$ \\
\hline \multicolumn{2}{|r|}{ Households } \\
\hline $\begin{array}{l}\text { Bankruptcy: } \\
\text { Liquidation }\end{array}$ & $\begin{array}{l}\text { Liquidation of the estate provides deserving debtors with a discharge of the } \\
\text { outstanding debt. It serves to operate a fresh start policy for over-indebted } \\
\text { individuals, by discharging the outstanding debt. Discharge should only be granted } \\
\text { to debtors that have not engaged in fraudulent conduct. }\end{array}$ \\
\hline $\begin{array}{l}\text { Bankruptcy: } \\
\text { Repayment Plans }\end{array}$ & $\begin{array}{l}\text { Repayment plans are an alternative to traditional bankruptcy (which is based on the } \\
\text { liquidation of the debtor's estate). A more modern modality of personal insolvency } \\
\text { proceedings allows debtors to retain (part of) their assets and commit to a } \\
\text { repayment plan for a specified period, after which the debtor receives a discharge. } \\
\text { These proceedings tend to be identified with the term "rehabilitation". }\end{array}$ \\
\hline Debt enforcement & $\begin{array}{l}\text { Debt enforcement offers creditors the possibility of recovering claims from the } \\
\text { debtor's assets. Debt enforcement is typically used in bilateral relationships, whereas } \\
\text { over-indebtedness typically involves multiple parties and requires insolvency. } \\
\text { Effective debt enforcement is a fundamental element that creates incentives for } \\
\text { payment discipline and for the conduct of proper restructuring negotiations } \\
\text { between debtors and creditors, and it is an essential element for secured credit. }\end{array}$ \\
\hline
\end{tabular}




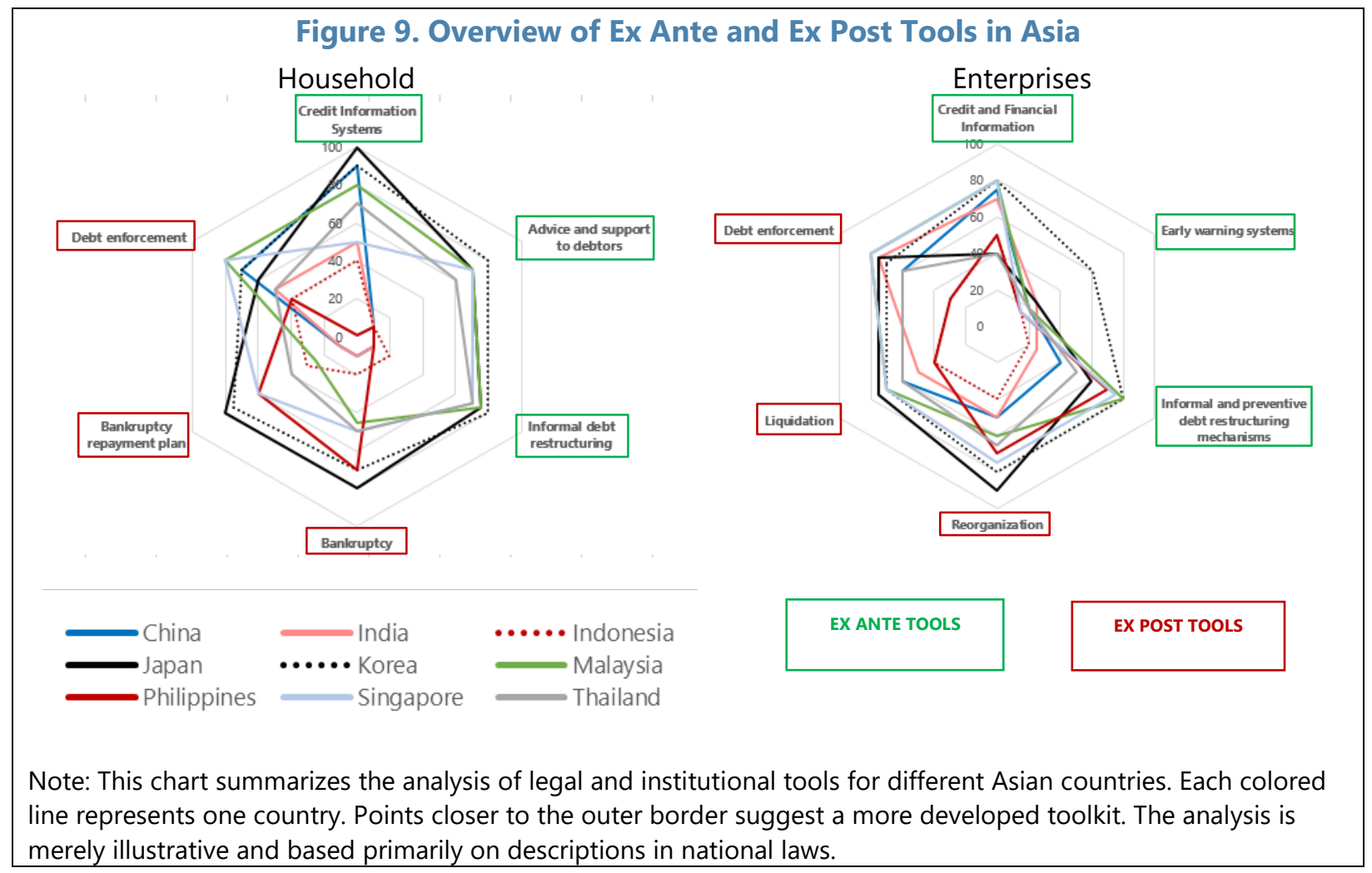

\section{A. Ex-ante Tools for Enterprises}

27. The development of preventive tools for enterprise over-indebtedness is fairly recent. Such techniques aim to avoid the costs of formal judicial insolvency proceedings and may also be effective at reducing the economic burden associated with elevated debt levels, thereby preserving the viability of enterprises. Ex-ante tools rely on the availability of financial and economic information and also include early warning systems and informal restructuring procedures. Figure 10 presents a summary of exante tools for enterprises in Asia, revealing gaps in early warning systems.

\section{(i) Credit and financial information}

28. Credit information systems tend to have a limited coverage of enterprises in Asian systems. In some countries, credit information systems have been designed mostly to gather information about consumer credit (Japan, Thailand, and the Philippines). In other cases, even if the systems collect positive and negative information on enterprises, the main source of information is the banking sector (China and India). However, given the importance of non-bank 
financial institutions, the coverage of enterprise liabilities offered by credit information systems is necessarily limited. That said, credit information systems in Korea, Malaysia, and Singapore have achieved wider coverage of enterprise liabilities.

29. The availability and quality of financial and economic information on enterprises is increasing in Asian systems. Asian systems have made progress in the implementation of regimes based on international financial reporting standards and establishing auditing systems. However, there is a clear gap between listed and unlisted companies regarding the quality of accounting information and the rules on disclosure of financial statements. In most Asian countries, only listed companies publish information on their financial statements. There is a trend to develop electronic systems for the submission and publication of financial statements.

\section{(ii) Early warning systems}

30. There is limited experience with early warning systems in ASEAN countries or in Asia. The policy of developing early warning systems, especially addressed at small and medium enterprises, has originated in Europe (France, Denmark). Only a few European countries have significant experience in the design of mechanisms that alert debtors of signs of distress and provide support for debt restructuring or other adequate changes to prevent insolvency. In advanced Asian economies, there is some reliance on the role of leading banks in monitoring the finances of small and medium enterprises and acting promptly to address enterprise distress at an early stage. In Korea, there is a developed system with stress indicators that are monitored by banks. This monitoring mechanism is tied to the corporate restructuring regime.

\section{For large enterprises, internal audit and risk management perform a similar} function to early warning systems. Large enterprises in ASEAN countries, and also in Asian countries generally, tend to have internal audit as a consequence of a statutory obligation or as part of the corporate governance code applied to listed companies. The existence of a risk management function increases the effectiveness of internal monitoring.

\section{(iii) Informal debt restructuring mechanisms}

32. Since the 1997 Asian crisis, countries have built up experience in the use of informal restructuring. Informal restructuring was widely used in the financial restructuring of enterprises in Thailand, Indonesia, Korea and Malaysia. Japan also developed a strong practice in the use of informal restructuring techniques. The legal culture in Asia is extremely receptive to negotiated solutions compared to adversarial litigation (Tomasic and Little, 1998), which explains the success of informal debt restructuring.

33. Informal debt restructuring mechanisms can be enhanced with the support of administrative authorities. The intervention of the administration can facilitate negotiations among the parties, beyond endorsing a set of principles informing those negotiations. Asian countries have been the pioneers in implementing this approach after the Asian crisis, and several countries have maintained enhanced debt restructuring mechanisms as part of the regular restructuring toolkit (Table 4). 


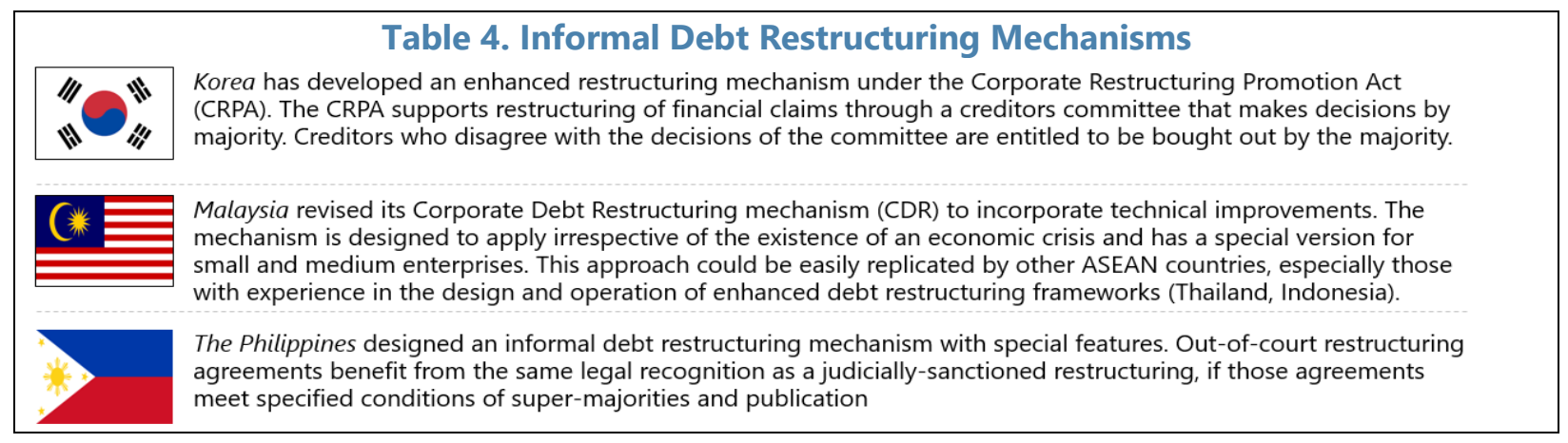

34. Due to the limitations of informal debt restructuring, there is a trend to complement them with preventive insolvency procedures. Informal debt restructuring faces constraints in cases where numerous creditors are involved and unanimous agreement on restructuring measures is unlikely. Preventive insolvency procedures are hybrid procedures, i.e., they benefit from limited judicial intervention, without incorporating the full set of rules and effects of a formal insolvency process. This means that the cost and impact of the procedures is limited, compared with a full reorganization.

35. Although there is no experience with preventive insolvency procedures in Asia, some countries use procedures that perform a similar function. In Malaysia and Singapore, for instance, it is possible to use schemes of arrangement to restructure distressed enterprises. Schemes of arrangement allow for a negotiation which results in a binding agreement for the debtor and all creditors, if the requisite majorities are reached. Intervention of the court is reduced, compared with formal insolvency proceedings. In other countries (Japan, Korea), there is some practice in "pre-packaged" reorganizations, which have similarities with preventive insolvency procedures, and allow companies to emerge from reorganization after a short judicial procedure.

36. In addition to the preventive techniques mentioned above, some countries have implemented support programs for indebted enterprises. These include advice for debt restructuring provided by financial and legal specialists, and in some cases, government guarantees. For micro- and small enterprises, this support can be connected with early warning systems and/or with informal debt restructuring mechanisms, as in the case of Korea and Japan.

\section{B. Ex-Ante Tools for Households}

\section{Preventive strategies against household over-indebtedness are increasingly}

important and seek to avoid the social cost of bankruptcy. Strategies to contain household debt follow different yet complementary approaches to corporate ones. General policies include financial education, financial consumer protection, macroprudential tools and policies for responsible lending. Techniques based on adequate legal infrastructure include collateral registries, valuation regimes and, especially, credit information systems - all of these are necessary for the effectiveness of macroprudential tools. The most important legal tool for the prevention of over- indebtedness, informal restructuring of debt, is also premised on the accuracy of the information provided by registries and credit information systems. The main preventive 
legal measures include: credit information systems, support and advice to debtors, and informal debt restructuring, including agreements to avoid insolvency.

38. Asian countries have developed preventive mechanisms to address household debt (Figure 11). Progress in financial inclusion has resulted in higher levels of household debt. Since social stigma and severe personal consequences are attached to bankruptcy, most legal systems in Asia have put in place restructuring solutions that avoid the use of the bankruptcy process.

\section{(i) Credit information systems}

39. Credit information systems are instrumental for containing household debt. They can collect information about credit relationships and payment patterns in other transactions, such as utilities and telecommunications. Some credit information systems in Asia have reached a wide coverage of the adult population (Figure 12). The situation in ASEAN countries is diverse, mainly due to differences in access to finance.

Expanding coverage is a necessary step to implement macroprudential policies and legal strategies to address household overindebtedness. ${ }^{20}$
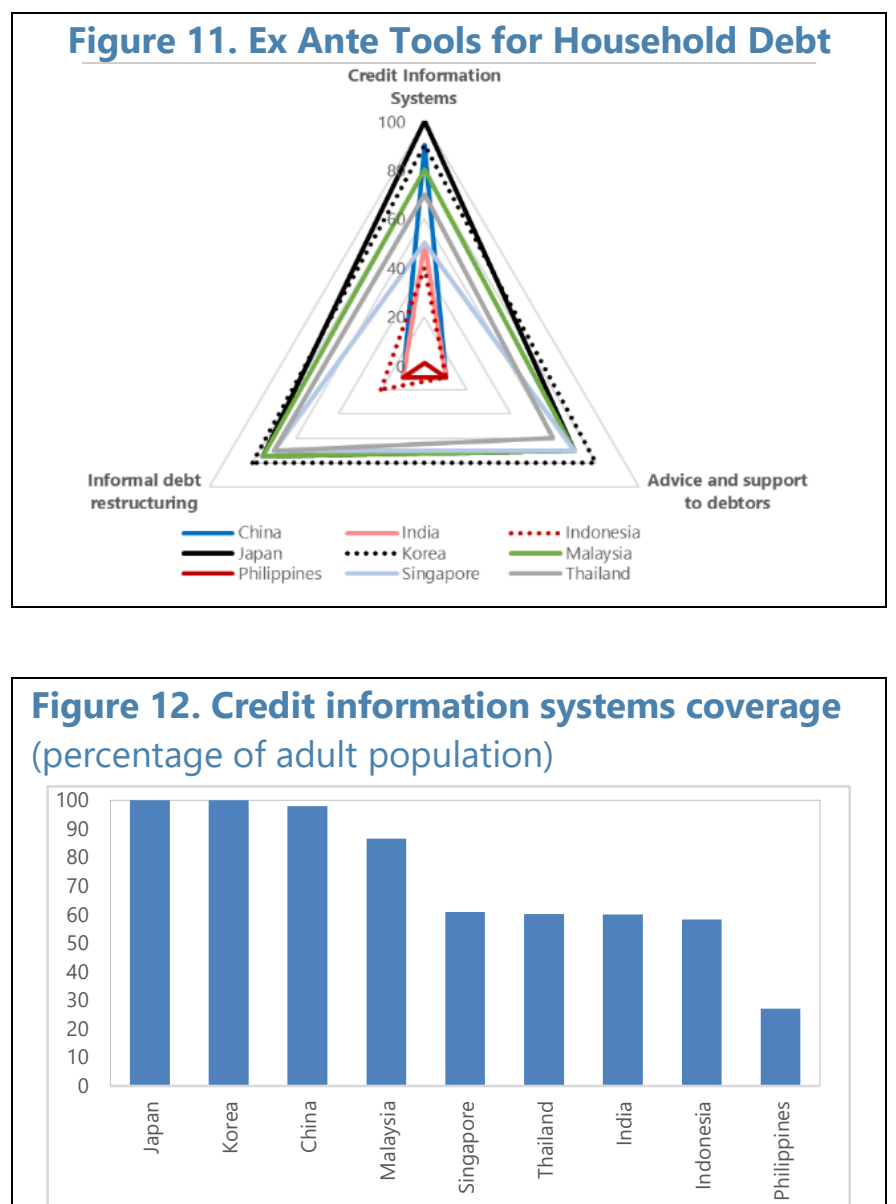

Source: Doing Business Report, 2019. The data includes the highest percentage among credit registry and credit bureau sources.

\section{(ii) Support to debtors}

\section{Specialized legal and financial advice is often needed when households are} confronted with debt problems. One of the most important issues for debtors' counseling is advice on the different options consumers have for restructuring their debts. Advice can be provided through dedicated public institutions or associations of lawyers and insolvency practitioners as pro bono programs or agreements with the public sector (Table 5).

\footnotetext{
${ }^{20}$ Fintech companies constitute new players in many Asian economies, which also collect and use credit information (for instance, in China). A gap in coverage may be exist where these entities are currently not included in most credit information systems.
} 
Table 5. Examples of Support to Debtors in Asia
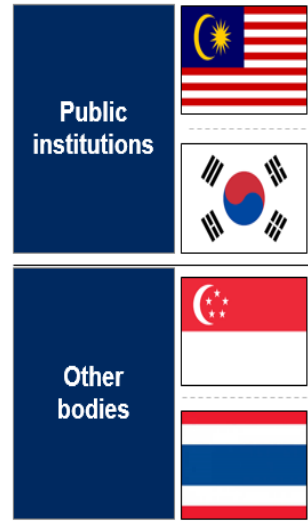

Malaysia: Bank Negara's Credit Counseling and Debt Management Agency (AKPK) offers free debt counseling to consumers and facilitates a number of debt-restructuring options.

Korea: Credit Counseling and Recovery Services (CCRS) was created as an initiative of the financial sector, but after several changes, it has re-emerged as a public agency, as part of the authorities' strategy to address household indebtedness.

\section{Informal debt restructuring (including agreements to avoid insolvency)}

41. Asia has experience with informal restructuring of household debt through various mechanisms that are typically linked to support programs to debtors. This can be done by establishing a mediating role for financial supervisors or specialized financial consumer protection authorities (Table 6).

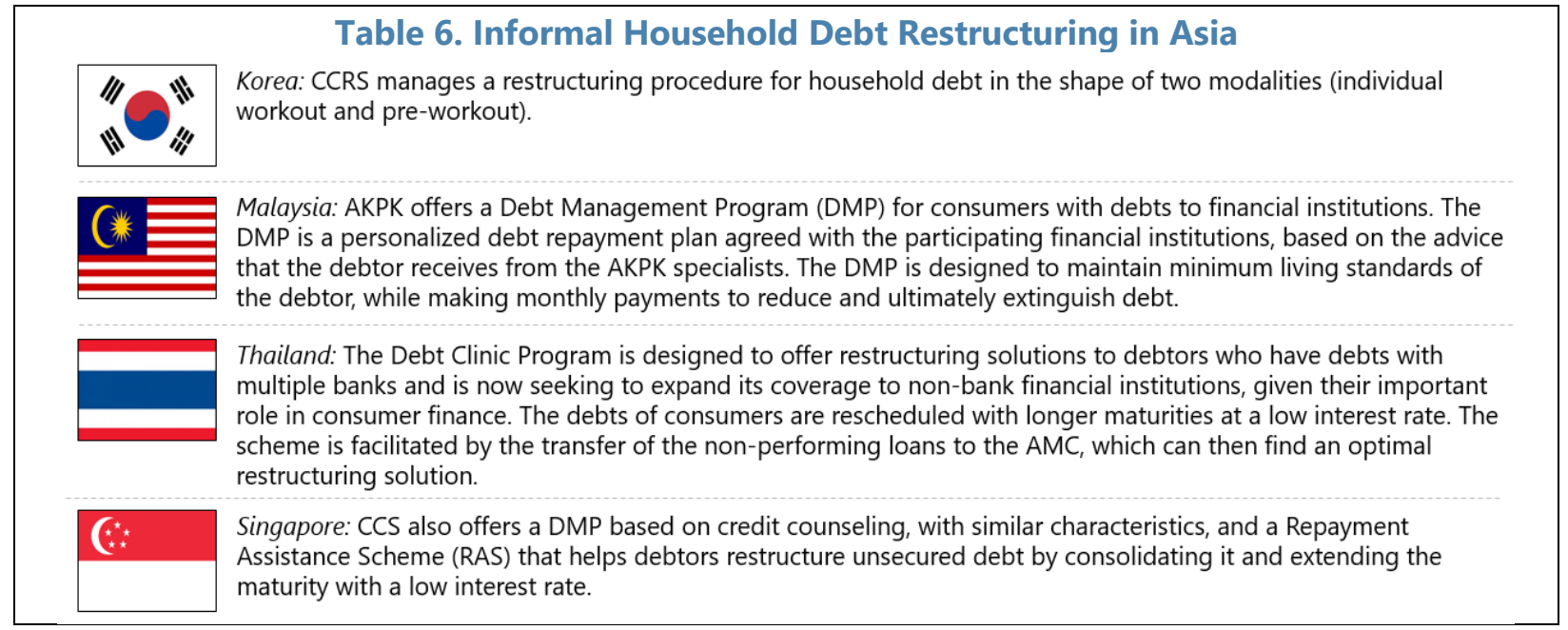

42. An agreement with creditors may be the last opportunity to avoid bankruptcy. As the costs of personal bankruptcy are extremely high in Asian countries, due to the stigma and the heavy restrictions imposed on debtors, legal systems tend to offer a last chance of avoiding bankruptcy by way of an agreement or settlement with creditors (Table 7).

\section{Table 7. Agreement with Creditors}

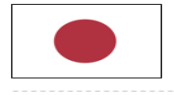

Japan has special conciliation proceedings to avoid personal bankruptcy. This consists of a negotiation of a debt restructuring agreement under the supervision of the court, but the agreement daes not impact the exercise of creditor rights and does not bind dissenting creditors.

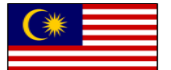

In Malaysia, debtors have the possibility of applying for a Voluntary Arrangement (VA). The AKPK offers support for this procedure. The Voluntary Arrangement is based on an application by the debtor to obtain an interim order from the court. If the creditors do not agree with the proposal prepared by the debtor's counsellor, the debtor will be declared bankrupt.

Thailand also offers the possibility of a "composition priar to bankruptcy", which represents the last chance to avoid the negative consequences of bankruptcy for the debtor. 


\section{Ex-Post Tools for Corporates}

43. Once enterprises become over-indebted, the legal system must provide tools for the resolution of insolvency. Even with the development of preventive tools, there will always be cases where enterprises accumulate unsustainable debt. Ex-post tools preserve viable enterprises - by reorganizing them - and redeploy assets to more productive uses - by liquidating the assets of non-viable enterprises (OECD, 2017). Effective insolvency regimes minimize the losses suffered by creditors in both cases and are generally associated with lower excessive leverage (Jarmuzek and Rozenov, 2019).

44. Asian insolvency systems have made significant progress in the last decades. At the time of the Asian crisis, enterprise insolvency regimes in the region, and in particular, in ASEAN countries, were insufficient and antiquated. The Asian crisis acted as a catalyst for insolvency reforms and raised awareness globally about the importance of insolvency regimes for financial stability. In many other countries, reforms have been introduced in the last decade (Philippines, Singapore, and Malaysia). In particular, many reforms have focused on the introduction and improvement of reorganization procedures. The situation in Asia today is dramatically different. Most countries have implemented insolvency frameworks that are largely inspired by best international practice (Figure 13).

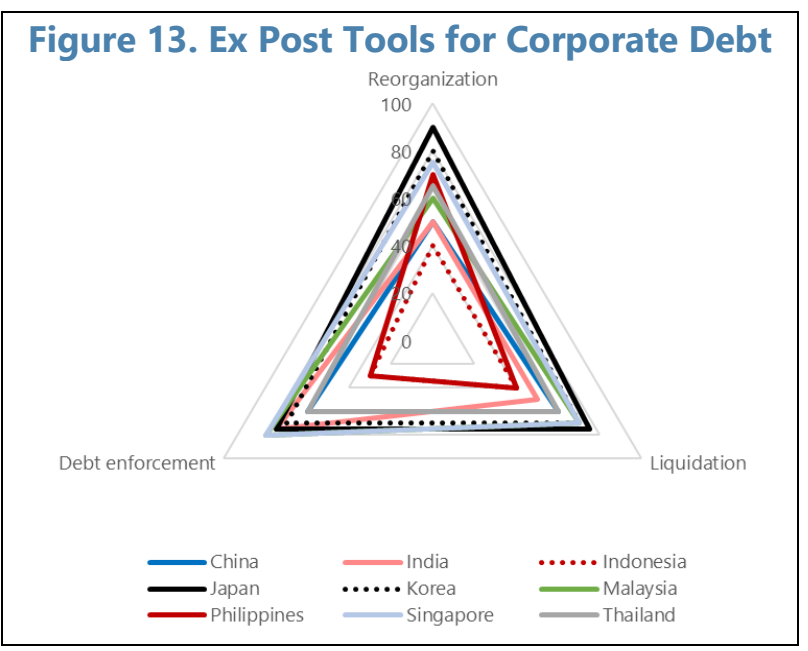

\section{(i) Reorganization}

45. Most Asian countries, including ASEAN, have introduced reorganization procedures. Reorganization procedures represent an integral part of the insolvency framework in the large economies (China, India, Japan, and Korea). However, there are important differences in practice: reorganizations are not frequent in China, whereas in in India, an attempt at reorganization is an essential part of every corporate insolvency procedure. Korea and Japan have reorganization regimes that more closely follow the international standard. Among ASEAN countries, Thailand introduced reorganization procedures after the crisis and has amended the law to include further improvements. The legal framework in Indonesia and the Philippines includes reorganization procedures, while Singapore and Malaysia have recently reformed their systems to introduce reorganization procedures too. However, there are important differences in the regulation of reorganization procedures which impact their effectiveness.

\section{(ii) Liquidation}

46. Liquidation proceedings are not particularly effective in Asia. Value destruction occurs because it is difficult to sell businesses as a going concern in the absence of large and developed markets for distressed enterprises. Selling assets piecemeal results in low recoveries 
and increased costs of the process, especially in the absence of qualified insolvency professionals.

\section{(iii) Debt enforcement}

47. Asian enforcement systems are generally effective, in varying degrees. Most countries in Asia require a judicial procedure for the enforcement of claims, including secured claims (China, Japan, Korea, Philippines, Indonesia, and Thailand). Enforcement of secured claims can take place out of court in some Asian countries (India, Malaysia, and Singapore). This suggests a division between civil law and common law systems.

48. Institutional quality impacts the effectiveness of ex-post tools. All ex-post tools are based on formal procedures. Therefore, the quality of the courts and of supporting professionals (insolvency professionals, bailiffs, appraisers) have a direct bearing on the effectiveness of the legal system. Some countries have created specialized insolvency courts (Thailand, Korea, China, and India). The development of a qualified insolvency profession is pending in most Asian systems. India has already implemented the new framework for the insolvency profession, and Singapore is planning to introduce a new regime for insolvency professionals. ${ }^{21}$

\section{Ex-Post Tools for Households}

49. Ex-post measures to address household over-indebtedness require insolvency procedures, with an increasing emphasis on rehabilitating debtors. This is achieved through the discharge of the debt, provided that the conditions set in the law are met. Among these conditions, typically debtors must surrender all assets except those protected by exemptions; and it may also be that debtors must devote their income, after deducting their living expenses, to the payment of their debts, for a specified period, before they earn a discharge of the remaining debt.

50. The regulation of personal insolvency is an outstanding issue in most Asian systems. Not all Asian countries have a personal insolvency system; China is an example. In some countries, personal insolvency is still inspired by notions of retribution against the defaulting debtor, such as in Malaysia or Singapore. In the absence of debt relief mechanisms, debtors may withdraw from the formal economy to escape creditor action. In addition, there are other factors that contribute to the low use of personal insolvency: the stigma attached to bankruptcy (Japan, Thailand, Malaysia, Indonesia, and Singapore); and the cost and duration of the process. Figure 14 provides a summary of the availability of ex-post tools for household debt in select Asian countries.

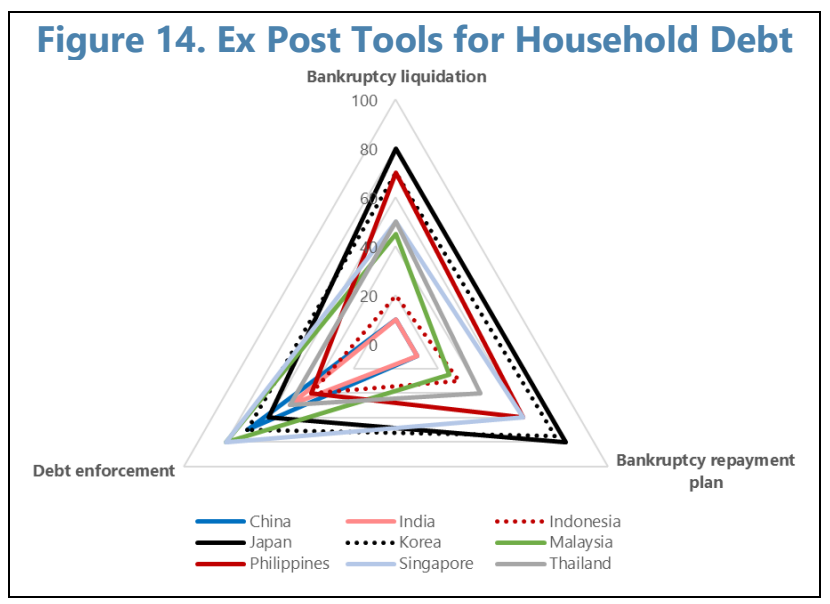

${ }^{21}$ In addition to the institutional framework, the creation of asset management companies (AMCs) can increase the effectiveness of ex-post tools, due to the inherent specialization and concentration of creditor rights. However, the creation of AMCs can also have anticompetitive effects. 
51. Liquidation of the estate provides deserving debtors with a discharge of the outstanding debt. In personal bankruptcy, liquidation has a very different connotation than in enterprise bankruptcy. While liquidation signals the end of the enterprise, liquidation of the assets of the debtor operates a "fresh start" for over-indebted individuals, by discharging the outstanding debt (World Bank, 2014). Discharge should only be granted to debtors that have not engaged in fraudulent conduct.

52. Asian countries tend to be restrictive in discharging debts of bankrupt individuals. Although Japan and Korea are closer to a fresh start policy, policies toward discharge remain restrictive in other countries (Table 8). Even in Japan and Korea, social prejudice towards bankrupt debtors represents a serious obstacle to a wider use of personal bankruptcy.

53. Providing a discharge to debtors with no assets may require a different approach. The main objective of personal bankruptcy is not debt collection, but the implementation of a fresh start policy. For debtors with no assets, it would be unreasonable to have a process that costs more than the debts it is supposed to address. In Korea and Japan, the practice of "simultaneous termination" refers to bankruptcies in cases where there are no assets, so that the procedure is terminated and only the part related to discharge continues. Other countries may therefore wish to consider specific mechanisms for granting discharge to debtors with no assets.

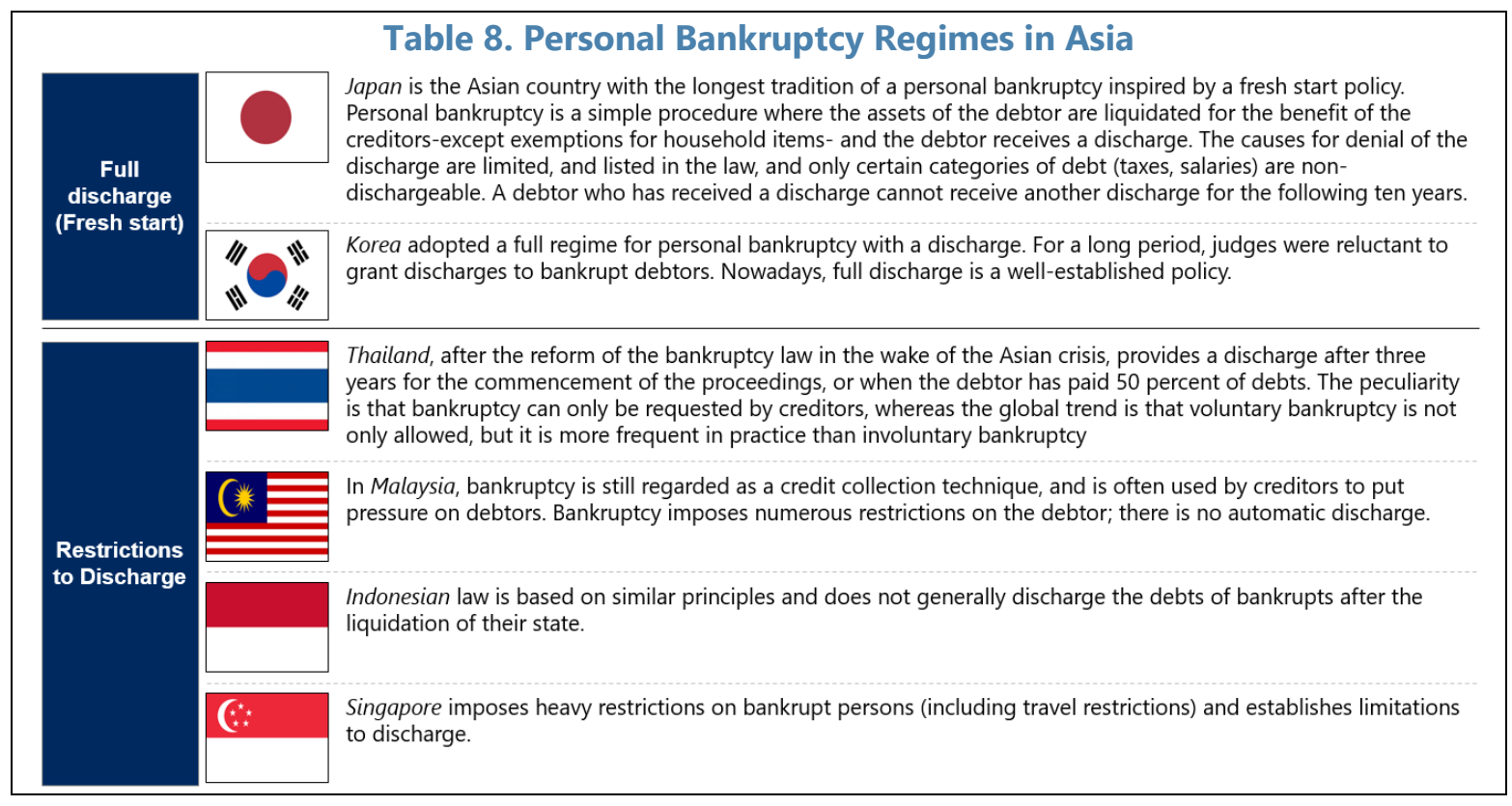

\section{(ii) Personal bankruptcy - repayment plans}

54. Some Asian countries are incorporating repayment plans in their personal insolvency legislation. Japan, following the U.S. model, introduced "special civil rehabilitation proceedings" where the debtor commits to making payments under a 3-year repayment plan. In the Korean individual rehabilitation proceedings, debtors must make payments within a 3-year repayment plan. The court can give a discharge even if the debtor does not make all payments 
under the plan, as long as creditors receive more than what they would have received in the bankruptcy of the debtor. In the Philippines, a suspension of payments scheme is granted to individual debtors (similar to that of enterprises), provided the debtor is solvent.

\section{(iii) Debt enforcement}

55. Debt enforcement tends to be effective in most Asian systems. Advanced economies in Asia tend to provide effective mechanisms for debt enforcement, especially for secured debts, but enforcement of debts remains a challenge in the lower income economies. The main problems are excessive delays and high collection costs. In some countries, enforcement of secured debts against individuals is fast, since it is possible to enforce without intervention of the courts (Malaysia, Singapore).

56. The institutional framework influences the effectiveness of the personal bankruptcy and debt enforcement regimes. In some countries, there are courts specialized in collection of small claims (India). Other countries have specialized enforcement agencies (Thailand). The development of an insolvency profession is extremely important for personal bankruptcy, as modern systems are based on the minimal intervention of judges and the performance of functions by qualified insolvency professionals.

\section{E. Legal Frameworks: Main Conclusions}

57. An evaluation of legal frameworks in ASEAN countries reveal certain gaps. The analytical approach used in this paper identifies areas where ASEAN systems could improve in order to have a more complete legal toolbox to tackle over-indebtedness of enterprises and consumers. These include:

- Critical ex-ante tools for over-indebted enterprises are missing. Although some systems have ample experience with informal debt restructuring, there is insufficient coverage of enterprise liabilities in credit information systems. The development of early warning systems would also represent a major improvement over the existing mechanisms to identify risks at an early stage, which only apply to large companies.

- Ex-post tools for over-indebted households need to be developed further. Many ASEAN systems are making important efforts in reinforcing preventive approaches to overindebtedness for households. These efforts could reflect the inadequacy of the ex-post regime: because personal bankruptcy regimes are repressive and bring with them legal sanctions and social stigma, policymakers are focusing on developing tools that avoid insolvency. However, ex-post tools are just as necessary as preventive tools, and ASEAN systems should also include personal insolvency procedures that grant a discharge on the basis of liquidation or a repayment plan.

- A market based-approach tends to be efficient. Debt resolution mechanisms function under the premise that the debtor and creditors will choose a rational course of action, reaching the most efficient economic solution (restructuring or liquidation). Ad-hoc or across-the board solutions, while useful in certain limited circumstances, fail to adequately distinguish the situation of different debtors and therefore generate inefficiencies. 
58. Ultimately, all countries need to refine existing tools to achieve a better treatment of over-indebtedness. In each ASEAN country, a granular analysis shows specific areas where the legal framework can be strengthened to provide better prevention and treatment of enterprise and household over-indebtedness. The extension of the model of specialized courts and, especially, the introduction of a regulated insolvency profession would improve the institutional capacity and the effectiveness of all these tools.

59. The design of new reforms of the legal framework should be based on systematic data collection. Traditionally, insolvency reforms have been designed without taking empirical data into consideration. New reforms should be backed by impact assessments and robust data collection (Garrido et al., 2019).

\section{F. The COVID-19 Shock and Private Debt Resolution}

\section{As in the rest of the world, the COVID-19 crisis has severely impacted ASEAN}

countries. The pandemic is having serious effects on healthcare systems. But the impact on the economy is expected be even more severe. Measures to fight the pandemic in most countries result in decreased economic activity, and there is uncertainty about the future of certain sectors such as tourism, retail, transportation. An increase in defaults and insolvency is to be expected.

61. The strategy to deal with over-indebtedness needs to be adjusted to address this new challenge (Figure 15). The preventive measures described in the previous section need to be reassessed in the face of an imminent crisis. Preventive measures, such as credit information and early warning systems, are designed to provide a better understanding of the buildup of debt in enterprises and individuals. However, in the context of a crisis where risks have already materialized, these systems will not produce valuable information. In essence, , wide sectors of the economy and population are likely to experience a significant deterioration in balance sheets, to a point where both credit information and early warning systems lose their utility. Conversely, other preventive mechanisms, especially debt restructuring tools that seek to avoid a formal insolvency proceeding, will be extremely useful in avoiding the collapse of the formal insolvency system under a potential wave of petitions. Just as in healthcare systems, it is important to adopt measures that "flatten the curve" of insolvencies and preserve the capacity of the judiciary to deal with the most complicated and urgent cases.

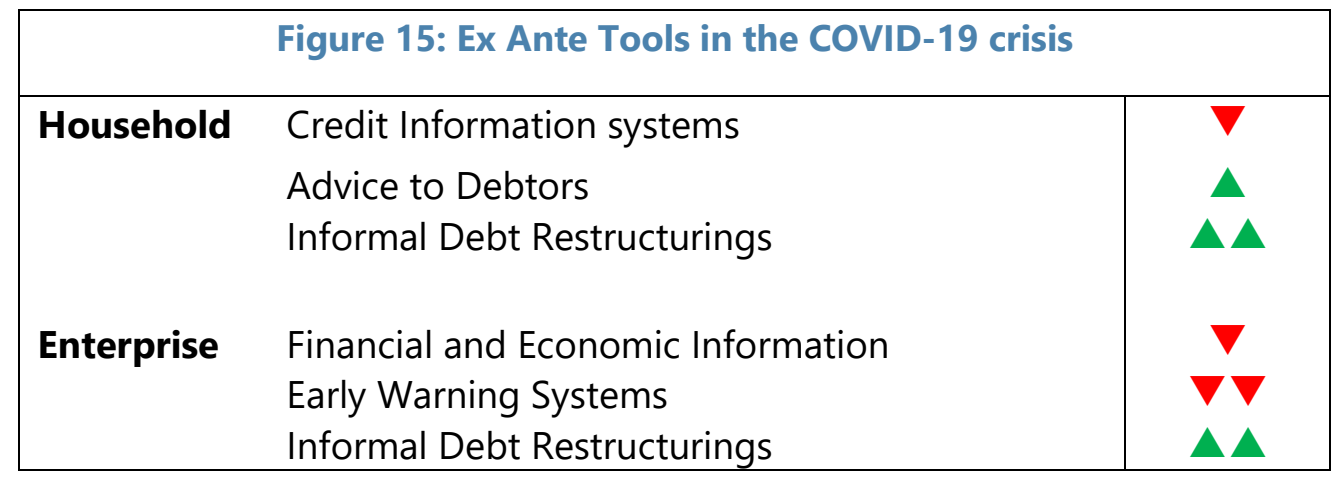


62. The insolvency crisis caused by the pandemic requires a sequential approach. Facing an increase of debt and a surge in defaults, it is likely that most countries will experience severe pressure on their ex ante and ex post mechanisms. Reforms to increase the capacity of the courts and reduce the length and complexity of insolvency procedures would be appropriate, but these reforms typically take time to be implemented effectively. For this reason, increasing the options and availability of debt resolution mechanisms outside the scope of the court system - the exante debt restructuring tools - would offer a better course of action for those countries where a wave of bankruptcy cases could result in the collapse of the judicial system. ${ }^{22}$ A strategy to overcome the special challenges of this crisis would involve the following three phases (Figure 16):

- Phase 1: Freeze. In the first phase, the debt enforcement and informal restructuring mechanisms will be affected by the emergency measures imposed in the context of the pandemic. In the midst of a lockdown, standard debt enforcement and insolvency procedures cannot continue as usual, and activity will have to be frozen, avoiding negative legal and economic consequences.

- Phase 2: Transition. After the emergency measures are lifted, the ordinary debt enforcement and insolvency system will restart. In some cases, this will be sufficient (i.e., some countries will be able to transition from Phase 1 to 3 ). However, other countries severely affected by the pandemic are likely to experience a wave of defaults that could overwhelm the judicial system. In this case, special out-of-court restructuring procedures and other special measures must be relied on to increase the capacity to resolve insolvency cases, especially those that involve viable companies.

- Phase 3: Fighting debt overhang. In phase 3, countries should tackle debt overhang by using all the elements of the standard insolvency and debt enforcement toolbox described in Section V. Countries should start assessing their systems to address the gaps as soon as possible, taking into account the time it takes to design, approve, and implement legal reforms.

Figure 16: Debt Resolution in the Wake of the COVID-19 Crisis

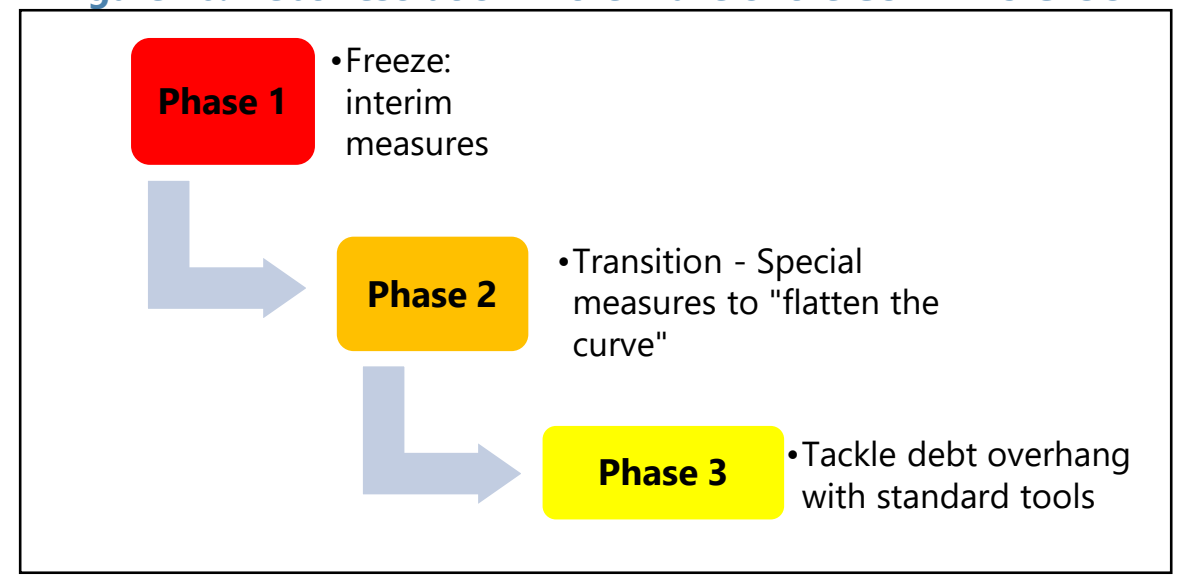

\footnotetext{
${ }^{22}$ Iverson (2018) has described in detail the negative effects caused by an overload of the bankruptcy courts: small enterprises tend to be liquidated without a chance for reorganization, and large cases are delayed.
} 


\section{Conclusion and Policy Recommendations}

63. This paper has examined the risks to growth that private leverage entails, and the growing risk from high and rising household debt. Despite potential short term gains, high private leverage can embed risks to growth in the medium term. There are also large monetary, legal and social costs with debt overhang and the formal resolution process. Experience tells us the costs of prevention can be lower than those of treatment, and a first best strategy of avoiding too much debt should be pursued. Nevertheless, where over-indebtedness does exist, it is important to have quick and low cost resolution strategies that rehabilitate economic agents to productive activity. The COVID-19 shock has crystallized the economic and social costs of high private debt, suggesting greater urgency in setting up appropriate debt resolution frameworks to deal with its challenges.

\section{Addressing over-indebtedness requires a comprehensive approach that includes macroeconomic and legal policies:}

- Macroprudential policies are important as both preventive and reactive measures (e.g., LTVs, DTI). However, macroprudential tools are not effective without good information on overall liabilities, servicing capacity, or collateral values.

- Fiscal policies can be preventive e.g. tax policy to remove debt bias for both corporates and households (eliminate mortgage deductions in personal income tax). They can also be reactive by providing support to over-indebted households. It is important that fiscal measures do not distort competition (i.e. no subsidies for failing enterprises).

- The current juncture shines the spotlight on legal policies and tools. The focus should be on preventive measures, including wider policies for consumers such as financial literacy, consumer protection, and responsible lending. These need to be combined with ex-post measures that influence the behavior of economic actors and make ex-ante measures more effective.

- Preventive systems have less capacity constraints in dealing with a high number of indebted corporations or households versus ex-post systems which can become overwhelmed, especially if deleveraging is systemic or large-scale.

- In a crisis situation such as the COVID-19 pandemic, a sequential approach is recommended. Measures such as out-of-court settlement procedures should be pursued to expedite orderly debt resolution without overwhelming the formal judicial system.

65. A strategy tailored to country specific circumstances should be prioritized. The analysis in this paper reveals the areas where countries can improve the most, namely ex-ante measures for corporates and ex-post tools for households. The spider charts provide a useful guide for countries to enact reforms where the gaps are largest, taking into account the time it takes to design, approve, and implement legal reforms. Other important considerations, such as balancing moral hazard of discharge with the need for encouraging risk taking and innovation and the appropriate balance of debtor vs. credit rights, should reflect country characteristics. 
66. The elements of the toolkit reinforce each other to have a cumulative effect in addressing over-indebtedness. There are tools that work better for certain cases; having a higher number of tools affords greater flexibility to deal with cases of over-indebtedness differently. At the same time, effective insolvency prevention mechanisms reduce the flow of cases and allow the court systems to be more efficient in dealing with those that make it to the courts. In short, there are many synergies between the different tools that this paper has brought out to help countries tailor strategies to deal with over-indebtedness in accordance with economic and social preferences.

67. The findings of this paper suggest several avenues for future research. The methodology developed to benchmark legal frameworks can be applied to countries in other regions, helping policymakers make informed decisions about priorities for reform. More broadly, a deeper understanding of the economic correlates of high private debt is warranted, including a sharper distinction between debt servicing and debt burdens for households, although the data requirements are likely to be binding, especially for emerging markets. Recent research by Mian et al. (2019) on the implications of household debt on inequality in the United States over the past few decades is a promising step in this direction. 


\section{Annex I. Methodology for the Analysis of Country Legal Systems}

The spider charts (Figures 9-13) included in the paper are a graphical representation of a qualitative assessment conducted on the ASEAN-5 countries (Indonesia, Malaysia, the Philippines, Singapore, and Thailand) and four large Asian countries (China, India, Japan, and Korea). The assessment of country systems is based on the analysis of legislation and on secondary sources.

The assessment focuses mostly on the existence of building blocks of systems for the prevention and treatment of over-indebtedness in the corporate and household sector. The degree to which the actual effectiveness of the systems is incorporated into the assessment is approximative, due to the lack of empirical information available. The numerical rating is generally based on a transposition of ROSC methodology ratings (i.e., non-compliant, 0-25; materially non-compliant, 26-50; largely compliant, 51-75; fully compliant, 76-100).

The specific methodological guidelines for the different blocks of the analysis are as follows:

\section{A. Ex Ante - Enterprise}

- Financial and economic information. This includes: credit bureau or credit registry for enterprises, access to financial information in public registries (if possible, including also small companies), accounting and auditing for large enterprises.

- Coverage of credit bureau (number of enterprises)

- Liabilities covered (financial and non-financial)

- Quality of accounting information for listed enterprises

- Quality of auditing

- Disclosure of accounts

- Disclosure of accounts for unlisted companies

- Early warning systems and support for indebted enterprises. This includes the special mechanisms designed for the detection of enterprise distress at early stages, whether connected with control mechanisms or designed as self-assessment tools and supported by specialized advice. The area also covers the existence of internal risk management and internal audit function at public listed companies. In addition, programs that are targeted to micro, small and medium enterprises to provide legal and financial advice to avoid overindebtedness should also be considered.

○ Early warning systems

- Internal risk management and internal audit

- Legal and financial advice for micro, small and medium enterprises

- Informal debt restructuring mechanisms and preventive insolvency procedures. This includes: debt restructuring principles; master restructuring agreements; enhanced debt restructuring procedures, with support from supervisors or other state administrations; 
preventive insolvency procedures, including hybrid procedures, i.e. out-of-court procedures supported by stay orders and/or fast-track confirmation (pre-pack) of negotiated restructuring agreements.

○ Debt restructuring principles

- Master restructuring agreements

$\circ$ Enhanced debt restructuring

○ Preventive insolvency procedures

\section{B. Ex Ante - Household}

- Credit information systems. This includes credit registries and credit bureaus and focuses on the coverage of the adult population and the type of liabilities covered:

- Coverage of adult population

○ Liabilities included in the system (financial, commercial)

- Advice and support to debtors. This includes all programs of support to distressed debtors, which may have the components of legal advice, debt counseling, and targeted financial support.

- Legal advice programs

○ Debt counseling

- Targeted financial support

- Informal debt restructuring and agreements to avoid insolvency. This includes supported ADR mechanisms to assist individuals with debt-related problems. This may include: mediation, conciliation, or arbitration. This may also include a code of conduct for financial institutions, and the intervention of financial authorities' (financial mediator or ombudsman, or a committee to deal with financial consumer intervention); and agreements to avoid insolvency (insertion of a phase in the insolvency process that avoids a declaration of bankruptcy by giving the debtor a last chance to reach an agreement with creditors).

- ADR (mediation, conciliation, arbitration)

- Financial consumer protection mechanisms

- Agreements to avoid insolvency: general availability and lack of obstacles for these agreements; existence of incentives or an obligation to seek the agreement before formal opening of bankruptcy.

\section{Ex Post-Enterprise}

- Reorganization. The analysis focuses on the following aspects of reorganization:

- Commencement criteria (broad standard means early reorganization is more likely)

- Debtor in possession/balance with protection against misconduct (DIP also means early reorganization is more likely) 
- Stay of creditor actions, with adequate protection of secured creditor provision of new finance

- Cram-down of minorities

- Executory contracts (and prohibition of ipso facto clauses)

- Simplified reorganization for small enterprises

- Liquidation. The analysis hinges on the existence of a functional liquidation framework, which requires a straightforward procedure, with no complications, allowing for the sale of the business as a going concern, or of business units, and properly supported by an adequate institutional framework of courts and insolvency professionals. rather than a piecemeal liquidation. The rating focuses on the following aspects:

- Streamlined liquidation procedure

- Flexibility in sale of the business

- Strength of the institutional framework

- Debt enforcement. Debt enforcement provides the general framework for the ex post treatment of indebtedness. The general functionality of the debt enforcement regime affects all the other elements of the treatment of indebtedness and over-indebtedness. In order to assess the system, the following factors can be taken into account:

- Streamlined procedures for debt enforcement (summary proceedings)

- Existence of specialized courts for debt enforcement (financial debts)

- Availability of out-of-court enforcement mechanisms

\section{Ex post- Household}

- Personal bankruptcy. The general assessment of the personal bankruptcy regime includes whether there is an existing regime for the insolvency of individuals, whether the regime is inspired by principles of rehabilitation (fresh start, discharge within a reasonable time) or if the regime is purely punitive. An additional factor is the efficient processing of debtors with no assets.

- Personal bankruptcy - repayment plans. The existence of an option that allows the debtor to repay part of the debts over a specified period, and retain ownership of certain assets (for instance, the debtor's primary residence) is assessed as an important part of the ex-post debt resolution regime.

- Debt enforcement. The debt enforcement regime applicable to individuals is one of the most important areas, influencing both ex ante and ex post strategies to deal with overindebtedness.

\section{Rating}

The rating given is based on the general effectiveness of the regime for the enforcement of secured debt and unsecured debt, the quality of the institutional framework (court system) and availability of out-of-court enforcement for secured debt. 
- Effectiveness of enforcement of secured debt

- Effectiveness of enforcement of unsecured debt

- Quality of institutional framework (including existence of specialize courts for small claims, or for financial claims)

- Availability of out-of-court enforcement for secured debt 


\section{References}

Adrian, Tobias; Boyarchenko, Nina; Giannone, Domenico, 2019, "Vulnerable Growth," American Economic Review; pp. 1263-89.

Alter, Adrian, Selim Elekdag, Alan Feng, Phakawa Jesakul, Romain Lafarguette, Prasad, A., and Changchun Wang,2019. "Growth at Risk: Concept and Application in IMF Country Surveillance” IMF Working Paper 19/36(Washington: International Monetary Fund).

Altman, Edward I. ,1968, "Financial Ratios, Discriminant Analysis and the Prediction of Corporate Bankruptcy," Journal of Finance, 23(4), 189.

Asian Development Bank, 2017. The Asian Bond Markets Initiative: Policy Maker Achievements and Challenges.

Bergthaler, Wolfgang, Chanda DeLong, Jose Garrido, Juliet Johnson, Amira Rasekh, Anjum Rosha, and Natalia Stetsenko, 2019, "The Use of Data in Assessing and Designing Insolvency Systems," IMF Working Paper 19/27 (Washington: International Monetary Fund).

Cecchetti, Stephen, M. Mohanty, and Fabrizio Zampolli, 2011, “The Real Effects of Debt," BIS Working Paper 352, September (Basel: Bank for International Settlements).

Gabriel, Garber, Atif Mian, Jacopo Ponticelli, and Amir Sufi, 2018, "Household Debt and Recession in Brazil," NBER Working Paper 25170 (Cambridge: National Bureau of Economic Research).

Gebauer, Stefan, Ralph Setzer, and Andreas Westphal, 2017, "Corporate Debt and Investment: A Firm Level Analysis for Stressed Euro Area Countries,” ECB Working Paper Series 2101 (Frankfurt: European Central Bank).

International Institute of Finance (2020). Global Debt Monitor (January).

IMF, 2012, "Dealing with Household Debt" World Economic Outlook, April (Washington: International Monetary Fund).

, 2016, Tax Policy, Leverage and Macroeconomic Stability, (October).

, 2017, "Household Debt and Financial Stability," Global Financial Stability

Report, October (Washington: International Monetary Fund).

,2017(a), "Macroprudential Policy and High Household Debt" Selected Issues,

2018 Korea Article IV Consultation.

,2019(a). “Republic of Korea, Selected Issues,” IMF Country Report, 18/41.

,2018, Asia and Pacific Regional Economic Outlook (April 2018). 
,2019(a). “People's Republic of China: 2019 Article IV Consultation," IMF Country Report, 19/266.

, 2019(b), "Lower for Longer," Global Financial Stability Report, October (Washington: International Monetary Fund). $19 / 233$ , 2019(a), "Singapore: 2019 Article IV Consultation" IMF Country Report No. , 2020, "Dampening Global Financial Shocks in Emerging Markets: Can Macroprudential Regulation Help?" World Economic Outlook, April (Washington: International Monetary Fund).

Iverson, B., 2018, "Get in Line: Chapter 11 Restructuring in Crowded Bankruptcy Courts", Management Science 64 (11): 5370. https://doi.org/10.1287/mnsc.2017.2808

Jácome, Luis. and Srobona. Mitra 2015. "LTV and DTI Limits—Going Granular," IMF Working Paper No. 15/154.

Jarmuzek, Mariusz and Rossen Rozenov, 2019, "Excessive private sector leverage and its drivers: evidence from advanced economies," Applied Economics, 51, 34.

King, Mervyn, 1994, “Debt Deflation: Theory and Evidence," European Economic Review, 38, 419-445.

Lamont, Owen, 1995, "Corporate Debt Overhang and Macroeconomic Expectations," The American Economic Review, (85), No. 5 (December), pp. 1106-1117.

Little, Peter and Roman Tomasic, 1998, "Corporate Insolvency and Self-help in Six Asian Legal Systems," 6 Insolvency Law Journal, 63.

Liu, Yan, José Garrido, and Chanda DeLong, 2020, "Private Debt Resolution Measures in the Wake of the Pandemic" IMF Special Notes (May).

Lombardi, Marco, Madhusudan Mohanty, and Ilhyock Shim, 2017, "The Real Effects of Household Debt in the Short and Long Run," BIS Working Paper 607, January (Basel: Bank for International Settlements).

Loukoianova, Elena Yu Ching Wong, and Ioana Hussiada, 2019. "Household Debt, Consumption, and Monetary Policy in Australia" IMF Working Paper 19/76.

Mian, Atif, Amir Sufi, and Emil Verner, 2015, "Household Debt and Business Cycles Worldwide," NBER Working Paper 21581 (Cambridge: National Bureau of Economic Research). , and Amir Sufi, 2017, "Household debt and business cycles worldwide," Quarterly Journal of Economics. 
,2018, "Finance and Business Cycles: The Credit-Driven Household Demand Channel," NBER Working Paper 24322 (Cambridge: National Bureau of Economic Research).

, Ludwig Straug, and Amir Sufi, 2019, “The Saving Glut of the Rich and the Rise of Household Debt" NBER Working Paper (Cambridge: National Bureau of Economic Research).

OECD, 2017, “Resilience in a Time of High Debt," Economic Outlook, Issue 2, Chapter 2

Reinhart Carmen and Kenneth S. Rogoff, 2010, "Growth in a Time of Debt," American Economic Review, pp. 573-578.

$\mathrm{Su}$, Jen-Je and Lixiong Yang, 2018, "Debt and growth: Is there a constant tipping point?" Journal of International Money and Finance, Elsevier, vol. 87(C), pages 133-143.

World Bank, 2014, Report on the Treatment of the Insolvency of Natural Persons. 